\title{
Geochronology of the central Tanzania Craton and its southern and eastern orogenic margins
}

Robert J. Thomas a, Christopher Spencer ${ }^{b, c}$, Alphonce M. Bushi ${ }^{d}$, Nick Baglowa, Nelson Boniface e, Gerrit de Kock a, Matthew S.A. Horstwood b, Louise Hollick ${ }^{\mathrm{f}}$, Joachim Jacobs g, Sperartus Kajara d, Godson Kamihanda d, Roger M. Key h, Zortosy Maganga d, Fabian Mbawala d, W. McCourt , Philip Momburi d, Fadile Moses d, Abdulkarim Mruma d, Yokbeth Myambilwa d, Nick M.W. Roberts b, Hamisi Saidi d, Petro Nyanda d, Khalid Nyoka d, Ian Millar b

\footnotetext{
${ }^{a}$ Council for Geoscience, Bellville, Polokwane and Pretoria Offices, South Africa

${ }^{\mathrm{b}}$ NERC Isotope Geosciences Laboratory (NIGL), British Geological Survey, Keyworth NG12 5GG, UK

c The Institute of Geoscience Research (TIGeR), Department of Applied Geology, Curtin University, Perth, Australia

${ }^{d}$ Geological Survey of Tanzania, Dodoma, Tanzania

${ }^{\text {e }}$ Department of Geology University of Dar-es-Salaam, Tanzania

${ }^{f}$ International Geoscience Services (IGS) Ltd, Nottingham NG12 5GG, UK

${ }^{g}$ Department of Earth Science, University of Bergen \& Norwegian Polar Institute, Fram Centre, Tromsø, Norway

${ }^{\mathrm{h}}$ Kalahari Key Ltd., Peebles, Scotland, UK
} 


\section{Abstract}

Geological mapping and zircon $\mathrm{U}-\mathrm{Pb} / \mathrm{Hf}$ isotope data from 35 samples from the central Tanzania Craton and surrounding orogenic belts to the south and east allow a revised model of Precambrian crustal evolution of this part of East Africa. The geochronology of two studied segments of the craton shows them to be essentially the same, suggesting that they form a contiguous crustal section dominated by granitoid plutons. The oldest orthogneisses are dated at ca. $2820 \mathrm{Ma}$ (Dodoma Suite) and the youngest alkaline syenite plutons at ca. $2610 \mathrm{Ma}$ (Singida Suite). Plutonism was interrupted by a period of deposition of volcano-sedimentary rocks metamorphosed to greenschist facies, directly dated by a pyroclastic metavolcanic rock which gave an age of ca. $2725 \mathrm{Ma}$. This is supported by detrital zircons from psammitic metasedimentary rocks, which indicate a maximum depositional age of ca. $2740 \mathrm{Ma}$, with additional detrital sources 2820 and $2940 \mathrm{Ma}$. Thus, $200 \mathrm{Ma}$ of episodic magmatism in this part of the Tanzania Craton was punctuated by a period of uplift, exhumation, erosion and clastic sedimentation/volcanism, followed by burial and renewed granitic to syenitic magmatism.

In eastern Tanzania (Handeni block), in the heart of the East African Orogen, all the dated orthogneisses and charnockites (apart from those of the overthrust Neoproterozoic granulite nappes), have Neoarchaean protolith ages within a narrow range between 2710 and $2630 \mathrm{Ma}$, identical to (but more restricted than) the ages of the Singida Suite. They show evidence of Ediacaran "Pan-African" isotopic disturbance, but this is poorly defined. In contrast, granulite samples from the Wami Complex nappe were dated at ca. 605 and ca. $675 \mathrm{Ma}$, coeval with previous dates of the "Eastern Granulites" of eastern Tanzania and granulite nappes of adjacent NE Mozambique. To the south of the Tanzania Craton, samples of orthogneiss from the northern part of the Lupa area were dated at ca. $2730 \mathrm{Ma}$ and clearly belong to the Tanzania Craton. However, granitoid samples from the southern part of the Lupa "block" have Palaeoproterozoic (Ubendian) intrusive ages of ca. 1920 Ma. Outcrops further south, at the northern tip of Lake Malawi, mark the SE continuation of the Ubendian belt, albeit with slightly younger ages of igneous rocks (ca. 1870-1900 Ma) which provide a link with the Ponte Messuli Complex, along strike to the SE in northern Mozambique.

In SW Tanzania, rocks from the Mgazini area gave Ubendian protolith ages of ca. 1980-1800 Ma, but these rocks underwent Late Mesoproterozoic high-grade metamorphism between 1015 and $1040 \mathrm{Ma}$. One granitoid gave a crystallisation age of ca. 1080 Ma correlating with known Mesoproterozoic crust to the east in SE Tanzania and NE Mozambique. However, while the crust in the Mgazini area was clearly one of original Ubendian age, reworked and intruded by granitoids at ca. $1 \mathrm{Ga}$, the crust of SE Tanzania is a mixed Mesoproterozoic terrane and a continuation from NE Mozambique. Hence the Mgazini area lies at the edge of the Ubendian belt which was re-worked during the Mesoproterozoic orogen (South Irumide belt), providing a further constraint on the distribution of ca. $1 \mathrm{Ga}$ crust in SE Africa.

$\mathrm{Hf}$ data from near-concordant analyses of detrital zircons from a sample from the Tanzania Craton lie along a $\mathrm{Pb}$-loss trajectory $(\mathrm{Lu} / \mathrm{Hf}=0)$, extending back to $\sim 3.9 \mathrm{Ga}$. This probably represents the initial depleted mantle extraction event of the cratonic core. Furthermore, the $\mathrm{Hf}$ data from all igneous samples, regardless of age, from the entire study area (including the Neoproterozoic granulite nappes) show a shallow evolution trend $(\mathrm{Lu} / \mathrm{Hf}=0.028)$ extending back to the same mantle extraction age. This implies the entire Tanzanian crust sampled in this study represents over 3.5 billion years of crustal reworking from a single crustal reservoir and that the innermost core of the Tanzanian Craton that was subsequently reworked was composed of a very depleted, mafic source with a very high 
Lu/Hf ratio. Our study helps to define the architecture of the Tanzanian Craton and its evolution from a single age-source in the early Eoarchaean.

\section{Introduction}

The Archaean Tanzania Craton has been well studied in many areas and its geological evolution is reasonably well understood. It has recently been reviewed from both tectonostratigraphic and metallogenic perspectives in Kabete et al., 2012a and Kabete et al., 2012b. In addition to craton-wide reviews, considerable focus has also been given to the cratonic margins where it is in contact with Palaeoproterozoic orogenic belts (Ubendian-Usagaran) in the SW, south and SE (e.g. Lawley et al., $\underline{2013}$ and Thomas et al., 2013) and the Neoproterozoic East African orogenic belt in the east (e.g. Johnson et al., 2003, Cutten et al., 2006, Thomas et al., 2013 and Thomas et al., 2014). According toKabete et al. (2012a) the older Palaeo- to Mesoarchaean basement of the Tanzania Craton comprises largely $>3140$ Ma diorite to granodiorite orthogneisses with inclusions of supracrustal rocks, including ca. 3600 Ma quartzite with 4013-3600 Ma detrital zircons from "as yet undetected" source terranes. This older basement is overlain by ca. 2823-2671 Ma granitoidgreenstone belts in northern (Lake Victoria region) and central Tanzania. Kabete et al., 2012a and Kabete et al., 2012b subdivided the Tanzania Craton into a number of broadly WNW-ESE trending terranes and "superterranes", based on differing lithotectonic and age criteria, noting that these continued south-eastwards into the East African Orogen where they were strongly reworked during the Neoproterozoic East African orogeny (see also Johnson et al., 2003 and Cutten et al., 2006). A study by Thomas et al. (2013) focussed on part of this marginal zone east of Dodoma and concluded that the boundary between the un-reworked Neoarchaean crust $(2.7 \mathrm{Ga})$ of central Tanzania was separated from the reworked Neoarchaean crust to the east by a mylonite zone with a top-to-the-NW sense of tectonic transport, and that this structure was initiated during the Palaeoproterozoic (Usagaran) tectonic event at ca. $1930 \mathrm{Ma}$ and reactivated during the Neoproterozoic East African orogeny.

Recent work by Mruma et al. (2009), Lawley et al. (2013), and Kazimoto et al. (2015)have shown that a similar situation occurs along the SW margin of the Tanzania Craton, where the supposedly Palaeoproterozoic "Lupa" and "Katuma" terranes (Daly, 1988) in fact comprise Neoarchaean crust (ca. 2.74-2.61 Ga) that was reworked and intruded by igneous rocks during the Palaeoproterozoic Ubendian orogeny at $1.96-1.88 \mathrm{Ga}$, in a continental magmatic arc setting. In the central Ubendian belt, SW of the Lupa terrane, Archaean crust is not recorded, but the (juvenile) Palaeoproterozoic rocks show evidence of re-working and suturing during both Mesoproterozoic and Neoproterozoic orogenic events (Boniface et al., 2012, Boniface and Schenk, 2012 and Boniface et al., 2014). The Geological Survey of Tanzania, in collaboration with BGS International (BGSi; now International Geological Services - IGS), the Council for Geoscience (CGS) of South Africa, and the Universities of Dar-es-Salaam, Tanzania and Bergen, Norway, undertook a World Bank-funded geological mapping project in a number of areas of Tanzania (Fig. 1). In order to gain an understanding of the whole of the southern part of the Tanzania Craton and its surrounding mobile belts, the selected areas focussed on two areas in the central part of the Tanzania Craton, termed "blocks" for convenience ("Singida" and "Dodoma" blocks), a large section across the East African Orogen ("Handeni block") and three smaller areas in the SE margin part of the craton ("Lupa", "Lake Malawi" and "Mgazini" blocks). 1:100 000 scale geological maps were produced of the blocks indicated in Fig. 1 along with accompanying explanatory notes. 
Geological mapping was undertaken of 17 Quarter Degree Sheets (QDS), and included representative sampling for whole-rock geochemistry and targeted $\mathrm{U}-\mathrm{Pb}$ zircon geochronology/ $\mathrm{Hf}$ isotope analyses of critical lithological units, in order to understand the tectonic evolution of the Tanzania Craton and its surrounding orogenic belts to the east and south.

The aim of this paper is to outline the findings of the new geological mapping within and around the Tanzania Craton, to present the new geochronological data, and to discuss the implications of the study results in terms of a new understanding of the architecture and evolution of the southern and east-central parts of the Tanzania Craton and its fringing orogens.

\section{Precambrian geology of the studied areas}

The central Tanzania craton was mapped in two areas, a northern (Singida) region, first studied by Eades and Reeves (1938) comprising four QDS, and a southern area of three QDS (Dodoma Block; Wade and Oates, 1938), a total area of some $20400 \mathrm{~km}^{2}$. The geology in both areas is comparable - both are dominated by gneissic granitoids ( $>90 \%$ of outcrops), with relatively minor greenstone belts of supracrustal rocks. The former are characterised mainly by grey tonalite, granodiorite, granite and syenite. Considerations of space preclude the presentation here of all the QDS geological maps produced, but as an example, a summary of the geology of the four maps of the Singida block are shown inFig. 2.

Some granitoids are strongly foliated (orthogneisses; typically tonalitic to granodioritic), while others are unfoliated (mainly granite and syenite). Outcrop is generally poor and relative age relations are unclear in the field. However, the large pink syenite bodies of the Singida area, for example, are clearly intrusive into older granitoids and very late in the intrusive sequence. Fragments and dismembered belts of greenschist to amphibolite facies supracrustal rocks, including psammitic and pelitic schists, quartzites and meta-volcanic rocks, some of which are clearly pyroclastic in origin, occur as enclaves within younger, less deformed plutonic rocks, but their field relationships with the granitoid orthogneisses is obscure. Rare post-tectonic granitic dykes up to one hundred metres wide occur in both blocks.

The volcanic rocks of the northern part of the Singida block comprising tholeiitic basalts, basaltic andesites and subordinate intermediate to felsic compositions were extruded at $2742 \pm 27 \mathrm{Ma}$ (8-point $\mathrm{Sm}-\mathrm{Nd}$ WR isochron), probably in a back-arc setting (Manya and Maboko, 2008). This date represents the only reported geochronology of the basement rocks in the Singida and Dodoma Blocks. Large granite plutons and associated vein networks intruded the volcano-sedimentary sequences prior to the emplacement of smaller syenitic plutons at the end of the Neoarchaean magmatic event. Deformation and accompanying low-grade metamorphism recorded in the volcanosedimentary rocks also affected the intruding granites (as shown by folded granite veins). Regional ductile shears (with associated gold mineralisation) cut the cratonic rocks prior to the emplacement of several phases of mafic dyke swarms. These are mainly made up of dolerites, the most abundant of which is a NE-SW trending swarm, which was recently shown to be Palaeoproterozoic (ca. $1775 \mathrm{Ma}$ ) in age (Mruma et al., 2014).

To the east of the craton, the Handeni Block comprised five surveyed QDS, covering a total of about $14500 \mathrm{~km}^{2}$. The Handeni Block is an extremely complex polyphase high grade metamorphic terrane with foliated meta-igneous (granitoids, metabasites and anorthosite complexes) and supracrustal rocks (metapsammites, pelites and carbonates) deformed and interlayered at all scales. These rocks, 
known broadly as the "Western Granulites" (e.g. Fritz et al., 2005) were first shown to have Neoarchaean protolith ages by Maboko (2000). Direct U-Pb zircon dating at ca. 2.6-2.7 Ga, were then obtained from locations outside of the current study area (Johnson et al., 2003, Sommer et al., 2005, Cutten et al., 2006 and Thomas et al., 2013). This basement complex was overthrust by granulite nappes ("Eastern Granulites"), mainly comprising two-pyroxene-bearing metabasites, charnockites and high-grade supracrustal rocks such as marbles, and were emplaced during the Neoproterozoic East African orogeny (e.g. Muhongo et al., 1999). The area contains meta-anorthosite complexes, one of which has been dated by U-Pb in zircon at ca. 2660 (Tenczer et al., 2011). The Handeni block contains two nappes, one of which, the Wami granulite nappe, contains garnet-bearing granulites and yielded a U-Pb zircon age of ca. $640 \mathrm{Ma}$ (recording peak granulite facies metamorphism;Muhongo et al., 1999) and Sm-Nd isochrons between ca. 580 and 618 Ma dating post-metamorphic cooling (Maboko, 2001).

The Lupa Block (Fig. 1) is located near Lake Rukwa. According to Daly (1988), it overlaps the SW edge of the Tanzanian craton and the adjacent Lupa terrane belonging to the Palaeoproterozoic Ubendian belt. However, a recent study by Lawley et al. (2013) has shown that at least part of the Lupa terrane is composed of ca. $2.74 \mathrm{Ga}$ Neoarchaean granitoids intruded by Palaeoproterozoic (1.96-1.88 Ga) calc-alkaline granitoids. In this model, the Lupa Terrane represents Ubendian-age crustal material accreted to the Archaean continental margin of the Tanzania craton. A tonalitic granitoid gneiss of the Katuma Series of the Ubendian Belt in the SW edge of the Tanzanian Craton provided ages of $2.64 \mathrm{Ga}$ (upper intercept) interpreted as minimum age for the tonalite and $0.7 \mathrm{Ga}$ (lower intercept) most probably representing an age of a major metamorphic event (Mruma et al., 2009).

Similar findings by Kazimoto et al. (2014) indicate that meta-basites and gabbro-norites of the Katuma Terrane (Daly, 1988) at the edge of the craton in the north of Lake Rukwa, are juvenile Neoarchaean rocks $(2.71-2.64 \mathrm{Ga})$ that formed along an active continental margin. The margin of the Tanzania craton and the Ubendian Belt was subsequently subjected to intrusion of several generations of juvenile mantle magmas and reworking of older Archaean rocks in Palaeoproterozoic, Mesoproterozoic and Neoproterozoic times (e.g. Boniface et al., 2012 and Kazimoto et al., 2014). The Lake Malawi block (Fig. 1) is located at the northern tip of Lake Malawi. The area is shown by Daly (1988) and Muhongo et al. (2002) to straddle the boundary between the Upangwa and Mbozi terranes of the Ubendian belt, although the geological characteristics of these "terranes" are not described in either publication. West of Lake Malawi, the basement outcrops comprise various schistose supracrustal sequences intruded by mafic to ultramafic igneous rocks with sheets of granitic orthogneiss termed the "Upangwa Meta-anorthosite Complex" by Harpum (1958). The mountains which rise abruptly from the NE shores of Lake Malawi are also composed of a similar association of supracrustal metasedimentary rocks intruded by meta-igneous, including anorthosite with magnetite layers and segregations, correlated with the Upangwa Meta-anorthosite Complex. This suggests that the purported Upangwa-Mbozi terrane boundary does not pass along the shores of the lake as shown in previous studies (see above). However, east of the Livingstone Mountains, the Ubendian rocks appear to have been thrust NE over another sequence of lower-grade phyllitic metamorphic rocks and meta-igneous rocks known as "Ukingan" (e.g. Harpum, 1958). Both the Ubendian and Ukingan rocks of this area are intruded by plutons of diorite, tonalite and granite collectively known as the "Ubena granites" (Harpum, 1958). Lenoir et al. (1994) reported a tonalitic orthogneiss from the Livingstone Mountains to have a protolith age of ca. $2085 \mathrm{Ma}$ that was deformed and intruded by granitic magmatism at ca. $725 \mathrm{Ma}$. 
The final study area (the Mgazini Block, Fig. 1), in a remote part of the Songea district, east of Lake Malawi, straddles the NE-trending Karoo-age Ruhuhu graben with high grade basement rocks to the NW and SE. The pre-Karoo geology of this area has never been investigated or mapped, and has previously been shown as forming part of the Palaeoproterozoic Ubendian and Usagaran belts, NW and SE of the graben, respectively (e.g. Pinna et al., 2004). The NW basement consists of large areas of quartzite and interlayered paragneiss intruded by pyroxenite bodies and large masses of granitic orthogneiss, some of which contain lenses of magnetite-bearing meta-anorthosite. The SE basement outcrops are dominated by high-grade meta-igneous rocks, including pyroxenite and mafic granulite, meta-anorthosite, charnockite and granitic orthogneisses similar to those seen to the NE. To the south of the Mgazini block Sommer and Kröner (2013) obtained emplacement ages (1158$1027 \mathrm{Ma}$ ) for the magmatic precursor rocks which were affected by UHT metamorphic reworking (770-730 Ma) during the early stages of the Neoproterozoic East African orogeny.

\section{Geochronological methods}

Thirty five fresh, representative samples of critical lithological units of around $5 \mathrm{~kg}$ mass were collected. Zircons from these samples were then analysed for $\mathrm{U}-\mathrm{Pb}$ and $\mathrm{Hf}$ isotopes. The locations of the samples are shown in Fig. 1 and GPS coordinates are given in Table 1. The samples were processed for zircon extraction using traditional techniques (i.e. Rogers table, heavy liquid (diiodomethane), Franz magnetic separation). Zircons were mounted in epoxy resin and polished to expose a cross section through the centre of the grains. Cathodoluminescence $(\mathrm{CL})$ and backscattered electron (BSE) images were made using an FEI Quanta 600 Scanning Electron Microscope.

\subsection{Laser ablation zircon $\mathrm{U}-\mathrm{Pb}$ geochronology}

Zircon $\mathrm{U}-\mathrm{Pb}$ geochronology was performed by either laser ablation single- or multi-collector inductively coupled plasma mass spectrometry (LA-SC/MC-ICP-MS). U-Pb analytical data, along with sample photographs are reported in supplementary information lodged with the journal's on-line data repository:

The instrumentation used for U-Pb analyses comprised a Nu Plasma HR multi-collector ICP-MS or an Atom single-collector ICP-MS (both Nu Instruments, Wrexham, UK) coupled to either a NWR193UC excimer laser ablation system with a TwoVol2 ablation cell, or a UP193SS Nd:YAG laser ablation system using a low-volume ablation cell (Horstwood et al., 2003; all laser instrumentation ESI, New Wave Research Division, Oregon, USA). Helium was used as the carrier gas through the ablation cell with Ar make-up gas being connected via a Y-piece and sourced from a Nu Instruments DSN-100 desolvating nebuliser. Analytical parameters and metadata are listed in supplementary information 1. On the MC-ICP-MS, masses ${ }^{202} \mathrm{Hg},{ }^{203} \mathrm{TI},{ }^{204} \mathrm{~Pb}+\mathrm{Hg},{ }^{205} \mathrm{TI},{ }^{206} \mathrm{~Pb},{ }^{207} \mathrm{~Pb},{ }^{235} \mathrm{U}$ and ${ }^{238} \mathrm{U}$ were measured with the $\mathrm{TI}$ and ${ }^{238} \mathrm{U}$ peaks being excluded during the SC-ICP-MS measurements to allow for increased measurement times on the other peaks. Hg traps are used in the system at NIGL-BGS, so it is not necessary to include a $\mathrm{Hg}$ correction. For SC-ICP-MS data ${ }^{238} \mathrm{U}$ was calculated from ${ }^{235} \mathrm{U}$ using $\mathrm{a}^{238} \mathrm{U} /{ }^{235} \mathrm{U}$ of 137.818 (Hiess et al., 2012). The $\mathrm{Pb} / \mathrm{Pb}$ and $\mathrm{U} / \mathrm{Pb}$ ratios were normalised to bracketing primary reference material 91500 , based on the average measured value of the reference material compared to the ratio determined by ID-TIMS (Wiedenbeck et al., 1995). Secondary reference materials GJ-1 and Plešovice were used to assess the accuracy of the normalisation (Jackson et al., $\underline{2004}$ and Sláma et al., 2008) and provide long-term variance statistics for uncertainty propagation $\left(0.76 \% / 1.7 \% 2 \mathrm{~s}^{207} \mathrm{~Pb} / 206 \mathrm{~Pb}\right.$ MC-ICP-MS/SC-ICP-MS respectively). Age interpretation used ${ }^{207} \mathrm{~Pb} /{ }^{206} \mathrm{~Pb}$ data in preference to $\mathrm{U}-\mathrm{Pb}$ data, after assessing the data to be concordant within $2 \%$. 
Analysis uncertainties represent measurement precision propagated with the excess variance of the reference material for the respective session. Age uncertainties are propagated for systematic components by quadratic addition and include the long-term variance of the reference materials on the ICP-MS, the uncertainties of the reference values as determined by ID-TIMS, and the decay constant uncertainties (e.g. Schoene et al., 2006). Total combined age uncertainties vary between 0.5 and 3\% (2 sigma; NB. conversion of analysis uncertainty to age uncertainty is not linear).

Visualisation of $\mathrm{U}-\mathrm{Pb}$ concordia and zircon ages is done using Isoplot v4.15 (Ludwig, 2012) and density plotter v5.0 (Vermeesch, 2012). Data were interpreted mostly preferring ages derived from $\mathrm{Pb}-\mathrm{Pb}$ ratios.

Results of $\mathrm{U}-\mathrm{Pb}$ and $\mathrm{Pb}-\mathrm{Pb}$ analyses for reference materials during nine single collector sessions and twelve multi-collector sessions spanning six months are presented in Table 2. Ratios for 91500 are self-normalised.

\subsection{Laser ablation zircon $\mathrm{Hf}$ isotopes}

Zircon ablation sites with near concordant (>95\% concordance) $\mathrm{U}-\mathrm{Pb}$ analyses from each of the samples were re-analysed to measure their respective Lu-Hf isotopic compositions. Isotope analyses were carried out using a Thermo Scientific Neptune Plus MC-ICP-MS coupled to a New Wave Research UP193UC excimer laser ablation system and a TwoVol2 ablation cell. Helium was used as the carrier gas through the ablation cell with Ar makeup gas being connected via a T-piece and sourced from a Cetac Aridus II desolvating nebuliser. After initial set-up and tuning, the nebuliser was aspirating air during the ablation analyses. Masses ${ }^{172} \mathrm{Yb},{ }^{173} \mathrm{Yb},{ }^{175} \mathrm{Lu},{ }^{176} \mathrm{Hf}+\mathrm{Yb}+\mathrm{Lu},{ }^{177} \mathrm{Hf},{ }^{178} \mathrm{Hf},{ }^{179} \mathrm{Hf}$ and ${ }^{180} \mathrm{Hf}$ were measured simultaneously using a $1 \mathrm{~s}$ integration time during a static, $30 \mathrm{~s}$ ablation analysis utilising a $35 \mu \mathrm{m}$ diameter spot and a fluence of $8-10 \mathrm{~J} / \mathrm{cm}^{2}$ (see Spencer et al., 2015 for full methods).

A standard-sample-standard bracketing technique, using zircons Mudtank and 91500 as reference materials, was employed to monitor accuracy and precision of internally corrected $\mathrm{Hf}$ isotope ratios and instrumental drift with respect to the Lu/Hf ratio. Hf reference solution JMC475 (both doped with $2 \mathrm{ppb} \mathrm{Yb}$ and undoped) was analysed during each analytical session to allow normalization of the laser ablation $\mathrm{Hf}$ isotope data. Correction for ${ }^{176} \mathrm{Yb}$ on the ${ }^{176} \mathrm{Hf}$ peak was made using a ${ }^{176} \mathrm{Yb} /{ }^{173} \mathrm{Yb}$ ratio calibrated for $\mathrm{Hf}$ mass bias using Yb-doped JMC475 solutions (c.f. Nowell and Parrish, 2001). Additionally, Plešovice and Yb-doped synthetic zircons (Zr141 and Zr142; Fisher et al., 2011) were analysed to assess the accuracy of the $\mathrm{Hf}$ ratio normalization and $\mathrm{Yb}$ ratio correction, respectively. ${ }^{176} \mathrm{Lu}$ interference on the ${ }^{176} \mathrm{Hf}$ peak was corrected by using the measured ${ }^{175} \mathrm{Lu}$ and assuming ${ }^{176} \mathrm{Lu} /{ }^{175} \mathrm{Lu}=0.02653$. Sample results are provided in supplementary information 2 .

Systematic uncertainties of $\mathrm{Hf}$ and Lu isotope ratios were propagated using quadratic addition, incorporating the external variance of the reference material during each analytical session.

Results of $\mathrm{Hf}$ analyses over nine sessions spanning three weeks, for 91500, Mudtank, Plešovice, and Yb-doped synthetic zircons, are presented below (Table 3). Hf ratios of Mudtank are self-normalised. Two $\mathrm{Yb}$-doped synthetic zircons containing varying amounts of $\mathrm{Yb}$ were also analysed. The lower $\mathrm{Yb}$ zircon $(\mathrm{Zr} 141, \mathrm{Yb} / \mathrm{Hf}=\sim 0.08)$ yielded a precise and accurate arithmetic mean within uncertainty of the preferred value. The higher $\mathrm{Yb}$ zircon $(\mathrm{Zr} 142, \mathrm{Yb} / \mathrm{Hf}=\sim 0.16)$ yielded a greater degree of scatter over the three week period and returned $>200 \mathrm{ppm}$ reproducibility within each daily session. Only 2 of the 341 sample analyses had $\mathrm{Yb} / \mathrm{Hf}$ ratios beyond the range of $\mathrm{Zr} 141$ and even for these analyses the average $\mathrm{Hf}$ isotope ratio did not deviate from the range determined from the low $\mathrm{Yb} / \mathrm{Hf}$ samples. It is therefore concluded that for this dataset the $\mathrm{Yb} / \mathrm{Hf}$ isobaric interference is accurately corrected. 


\section{Bulk-rock Rb-Sr and Sm-Nd geochemistry methods}

Solution isotopic analyses were obtained by HF-HNO3 digestion of non-ignited whole-rock samples at the Natural Environment Research Council Isotope Geoscience Laboratory (NIGL). Light rare earth elements (LREE) were concentrated using Eichrom AG50 cation exchange columns. Neodymium and samarium were loaded onto double-rhenium filament assemblies, and analysis was undertaken in multi-dynamic mode on a Thermo Scientific Triton thermal ionisation mass spectrometer. ${ }^{143} \mathrm{Nd} /{ }^{144} \mathrm{Nd}$ is reported normalised to a preferred value of 0.512115 for the JNd-i standard (Tanaka et al., 2000). Measured ${ }^{143} \mathrm{Nd} /{ }^{144} \mathrm{Nd}$ ratios for the La Jolla standard are $0.512106 \pm 0.000010(2$ sigma $=18 \mathrm{ppm}, n=15)$.

\section{Geochronology}

In the following section, the data from each of the major sampling areas are described (see Fig. 1). The 35 samples were carefully selected from several hundreds of samples collected in order to best represent the various supracrustal rock sequences mapped and the intrusive sequence in each area. The samples are subdivided into eight groups, based on the geochronological results, as numbered below. Ages are preferentially derived from weighted mean ${ }^{207} \mathrm{~Pb} / 206 \mathrm{~Pb}$ ratios of concordant data unless stated otherwise. All age and $\varepsilon \mathrm{Hf}$ uncertainties are propagated at the $2 \mathrm{~s}$ level.

\subsection{Central Tanzania Craton "core" (Dodoma and Singida blocks)}

From the geochronological data, it is clear that the granitoids fall into two distinct age groups, separated by the formation of the supracrustal rocks. Due to poor outcrop, this division was not clear from the field evidence, except that it was clear that some granitoids contained enclaves of supracrustal rocks and were thus younger. The older suite, mainly comprised of orthogneisses is termed here the "Dodoma Suite", while the post-supracrustal granitoids, largely unfoliated is termed the "Singida Suite".

\subsubsection{Older igneous rocks (Dodoma Suite)}

Five samples of the Dodoma Suite were dated and the results are illustrated in Fig. 3.

\subsubsection{Sample 102_216}

This sample is a medium-grained leucocratic biotite granite composed of quartz, K-feldspar, minor plagioclase and biotite. In Fig. 3 the $\mathrm{U}-\mathrm{Pb}$ analyses are colour-coded by ${ }^{204} \mathrm{~Pb}+\mathrm{Hg}$ (common lead) content. The origin of the common lead is likely due to post-crystallisation processes associated with a lead-loss event. Analyses with low levels of ${ }^{204} \mathrm{~Pb}+\mathrm{Hg}(<300 \mathrm{cps})$ group as a single population of ${ }^{207} \mathrm{~Pb} /{ }^{206} \mathrm{~Pb}$ ages with a mean age of $2775 \pm 23 \mathrm{Ma}$. The $\mathrm{Pb}$-loss trends observed may be consistent with disturbance during the East African Orogen (ca. $550 \mathrm{Ma}$ ). $\mathrm{Hf}$ analyses of selected $\mathrm{U}-\mathrm{Pb}$ spots used in the age determination have a single population $\varepsilon \mathrm{Hf}$ at $1.98 \pm 0.62$ (c.f. expected depleted mantle value of $\sim 7$ at $2775 \mathrm{Ma}$ ).

\subsubsection{Sample AMB_178_80}

This granodioritic orthogneiss is composed of quartz, plagioclase, subordinate K-feldspar and biotite ( \pm hornblende). In Fig. 3, U-Pb analyses are colour-coded by ${ }^{204} \mathrm{~Pb}+\mathrm{Hg}$ (common lead) content, with high common lead. The presence of common lead is likely evidence for open system behaviour. The $\mathrm{U}-\mathrm{Pb}$ analyses are highly with $\mathrm{Pb}-$ loss trends consistent with disturbance during the East African 
Orogen. Two analyses with low levels of ${ }^{204} \mathrm{~Pb}+\mathrm{Hg}(<300 \mathrm{cps})$ give a mean ${ }^{207} \mathrm{~Pb} /{ }^{206} \mathrm{~Pb}$ age of $2782 \pm 32 \mathrm{Ma}$ that is interpreted to be the best estimate for the crystallisation age of the orthogneiss protolith. $\mathrm{Hf}$ analyses of $\mathrm{U}-\mathrm{Pb}$ analyses used for age determination define a single population $\varepsilon \mathrm{Hf}$ at $-0.4 \pm 1.4$ (c.f. depleted mantle value of $\sim 7$ at $2782 \mathrm{Ma}$ ).

\subsubsection{Sample FMP_106}

This granodioritic orthogneiss has with similar mineralogy to the previous sample. Many of the $\mathrm{U}-\mathrm{Pb}$ analyses are heavily discordant, but a subset of the least discordant points has an upper intercept age of $2740 \pm 17 \mathrm{Ma}$. $\mathrm{Hf}$ analyses of selected $\mathrm{U}-\mathrm{Pb}$ spots define a single population $\varepsilon \mathrm{Hf}$ at $2.97 \pm 0.69$ (c.f. depleted mantle value of $\sim 7$ at $2740 \mathrm{Ma}$ ).

\subsubsection{Sample FMP_A273W}

$\mathrm{U}-\mathrm{Pb}$ analyses of this granitic orthogneiss (composed of quartz $+\mathrm{K}$-feldspar, subordinate plagioclase and biotite) are variably discordant with a single population of $<2 \%$ discordant analyses giving a mean ${ }^{207} \mathrm{~Pb} /{ }^{206} \mathrm{~Pb}$ age of $2823 \pm 13 \mathrm{Ma}$. $\mathrm{Hf}$ analyses of this population of $\mathrm{U}-\mathrm{Pb}$ spots gave a mean $\varepsilon \mathrm{Hf}$ of $-0.2 \pm 0.2$ (c.f. depleted mantle value of 6.5 at $2823 \mathrm{Ma}$ ).

\subsubsection{Sample SK_390}

This sample is a medium-grained granodiorite, with the mineralogy quartz-plagioclase-K-feldspar and biotite. U-Pb analyses are variably discordant with a well-defined upper intercept at $2742 \pm 14 \mathrm{Ma}$. $\mathrm{Hf}$ analyses for these analytical spots have a mean $\varepsilon \mathrm{Hf}$ of $1.6 \pm 0.5$ (c.f. depleted mantle value of $\sim 7$ at $2742 \mathrm{Ma})$.

\subsubsection{Supracrustal rocks}

Four greenschist facies grade supracrustal rocks were analysed, including three psammitic metasedimentary rocks with detrital zircons and one metamorphosed pyroclastic volcanic rock (Fig. 4).

\subsubsection{Sample SK_499}

This quartzite was taken from a prominent ridge within the granitoid country rocks. It is fairly pure (with a little mica), coarse-grained and strongly recrystallised. The U-Pb analyses of detrital zircons are widely discordant. They cover an apparently triangular area in the concordia diagram with a lower anchor point at about $500 \mathrm{Ma}$ and upper intercepts ranging from ca. 2.7 to $3.8 \mathrm{Ga}$. U-Pb spots with $<2 \%$ discordance analysed for $\varepsilon \mathrm{Hf}$ cluster near 0 (value of the chondrite uniform reservoir) at 3.63.8 Ga with younger analyses forming a trajectory with a $\mathrm{Lu} / \mathrm{Hf}$ slope of 0 which implies the $\mathrm{U}-\mathrm{Pb}$ ages are the product of lead loss anchored likely at $\sim 3.8 \mathrm{Ga}$. This further implies that the sample had a relatively simple initial age distribution around 3.6-3.8 Ga with a lead-loss event at $\sim 2.7 \mathrm{Ga}$ and a second lead-loss event during the Pan-African Orogeny at ca. $0.5 \mathrm{Ga}$. This interpretation may have application to the $>3600 \mathrm{Ma}$ zircon ages reported by Kabete et al. (2012a) in that these ages may be explained by lead loss of an older still unidentified crustal source.

\subsubsection{Sample FMP_85AW}

The $\mathrm{U}-\mathrm{Pb}$ analyses of this cleaved impure greywacke metasediment are variably discordant with two populations of $<2 \%$ discordant analyses. Discordant analyses project to both of the two concordant populations. The youngest population forms a coherent group of eight analyses with a mean of $2744 \pm 14 \mathrm{Ma}$. We interpret this to represent the maximum depositional age of this sedimentary unit. 
The older population ranges from $2820 \mathrm{Ma}$ to $2940 \mathrm{Ma}$ but does not form a statistically identifiable single population. $\mathrm{Hf}$ analyses of selected $\mathrm{U}-\mathrm{Pb}$ spots from the younger population have a mean of $1.68 \pm 0.55$ (c.f. the depleted mantle $\varepsilon \mathrm{Hf}$ of $\sim 7$ at $2774 \mathrm{Ma}$ ).

\subsubsection{Sample AMB_178_58}

This sample is a greenschist grade metavolcanic rock with mafic bombs. The analytical data are strongly discordant but a subset of 6 points at $<2 \%$ discordance forms a scattered population with mean age of $2725 \pm 36 \mathrm{Ma}$. We interpret this age to represent the volcanic emplacement of this volcanic unit. $\varepsilon \mathrm{Hf}$ of these concordant grains is $-3.2 \pm 1.2$ (c.f. the depleted mantle $\varepsilon \mathrm{Hf}$ of $\sim 7$ at $2725 \mathrm{Ma})$.

\subsubsection{Sample FMP_460}

This sample of pure strongly recrystallised quartzite sample yielded very few small zircons which gave only a poorly defined discordia. $\mathrm{U}-\mathrm{Pb}$ analysis gave an upper intercept age of $\sim 2.7 \mathrm{Ga}$. The zircons were too small to analyse for $\mathrm{Hf}$ isotopes.

\subsubsection{Younger igneous rocks (Singida Suite)}

Seven samples of the Singida Suite were dated and the results are illustrated in Fig. 5.

\subsubsection{Sample SK 553}

This sample is of a late unfoliated granite dyke which cross-cuts older granitoid orthogneisses of the Dodoma Block. It is composed of quartz. K-feldspar, plagioclase, biotite and hornblende. The analytical data are variably discordant with two populations of $<2 \%$ discordant analyses. Discordant analyses project to both populations. The younger population forms a coherent group of 22 analyses with a mean of $2727 \pm 31 \mathrm{Ma}$, interpreted to be the best estimate for the emplacement age of the dyke. The older population ranges from $2800 \mathrm{Ma}$ and $2900 \mathrm{Ma}$ but does not form a statistically identifiable single population. These older zircon are interpreted to represent inherited (xenocrystic) components in the dyke. Hf analyses of selected U-Pb spots of the 2727 Ma zircon population have a mean $\varepsilon \mathrm{Hf}$ of $-1.42 \pm 0.77$ indicative of a crustal component in generation of the melt (c.f. expected depleted mantle value of $\sim 7$ at $2727 \mathrm{Ma}$ ).

\subsubsection{Sample 102_005}

The $\mathrm{U}-\mathrm{Pb}$ analyses of zircons from this coarse-grained, feldspar-porphyritic biotite granite form a heavily discordant dataset, but a subset of three spots with $<2 \%$ discordance define a single population with a mean age of $2700 \pm 34 \mathrm{Ma}$, interpreted as the best estimate for emplacement of the granite, and a potential inherited component at $\sim 2.9 \mathrm{Ga}$. The data show an apparent Neoproterozoic ("Pan-African") lower intercept age. $\mathrm{Hf}$ analyses of selected $\mathrm{U}-\mathrm{Pb}$ spots of the young condordant group of zircon, have single population $\varepsilon \mathrm{Hf}$ at $0.07 \pm 0.75$ (c.f. calculated depleted mantle value of $\varepsilon \mathrm{Hf}$ of ca. 7 at $2700 \mathrm{Ma}$ ).

\subsubsection{Sample SK 106}

This sample is a late, cross-cutting late granite dyke from the Dodoma block, composed of quartzmicrocline-plagioclase-biotite. $\mathrm{U}-\mathrm{Pb}$ data are variably discordant with a mean age of $2675 \pm 32 \mathrm{Ma}$, interpreted as the crystallisation age of the dyke, and potential inheritance up to $3000 \mathrm{Ma}$. $\mathrm{Hf}$ analyses of selected $\mathrm{U}-\mathrm{Pb}$ spots have a mean $\varepsilon \mathrm{Hf}$ of $-1.11 \pm 0.67$ (c.f. calculated depleted mantle value of $\varepsilon \mathrm{Hf}$ of $\sim 7$ at $2675 \mathrm{Ma}$ ). 


\subsubsection{Sample FMP_A248}

$\mathrm{CL}$ images of zircons from this medium-grained, biotite-bearing granitic orthogneiss reveal complex zoning patterns with distinct core and rim structures. Despite the presence of rims, and thus inferred inheritance in the $\mathrm{CL}$ images, the $\mathrm{U}-\mathrm{Pb}$ analyses show a unimodal population constrained by a discordia and variable lead loss. A subset of 5 points in that population with $<2 \%$ discordance gives a mean age of $2714 \pm 26 \mathrm{Ma}$. This age is interpreted to represent the age of emplacement of the orthogneiss protolith.

\subsubsection{Sample 102_051}

This very coarse-grained pink-weathering, fluorite-bearing syenite is composed almost entirely of microcline microperthite with minor biotite. Complex zoning patterns are seen in CL images with corerim phases and intensely metamict textures. However, the $\mathrm{U}-\mathrm{Pb}$ analyses are largely concordant, of which 10 points $<2 \%$ discordant define a population with a single mean age of $2612 \pm 32 \mathrm{Ma}$ and a potential inherited component at $\sim 2.8 \mathrm{Ga}$. $\mathrm{Hf}$ analyses of selected $\mathrm{U}-\mathrm{Pb}$ spots have $\varepsilon \mathrm{Hf}$ at $-0.07 \pm 0.40$ (c.f. depleted mantle value of $\sim 7$ at $2612 \mathrm{Ma}$ ).

\subsubsection{Sample FM_78_AW}

$\mathrm{U}-\mathrm{Pb}$ analyses of zircons from this biotite granite, shown in Fig. 5 are colour-coded for ${ }^{204} \mathrm{~Pb}$ (common lead) content, the origin of which is likely due to post-crystallisation processes and a lead-loss event. Nine analyses with low levels of ${ }^{204} \mathrm{~Pb}+\mathrm{Hg}(<300 \mathrm{cps})$ define a discordia line with an upper intercept at $2678 \pm 44 \mathrm{Ma}$, which is interpreted to be the age of emplacement of the granite and a poorly constrained "Pan-African" lower intercept. Hf analyses of selected $\mathrm{U}-\mathrm{Pb}$ spots give a single population $\varepsilon \mathrm{Hf}$ at $-0.42 \pm 0.82$ (c.f. depleted mantle value of $\sim 7$ at $2678 \mathrm{Ma}$ ).

\subsubsection{Sample SK_256}

This sample is from a late granite dyke from the Singida block which is near-identical to those intruding the Dodoma Block (e.g. sample SK_553). The U-Pb data are heavily discordant. In Fig. 5 , the data points are colour-coded by ${ }^{204} \mathrm{~Pb}+\mathrm{Hg}$ (common lead) content. The origin of the common lead is probably due to post-crystallisation processes associated to a lead-loss event. Analyses with acceptable levels of ${ }^{204} \mathrm{~Pb}\left(<300 \mathrm{cps}\right.$ ) define a single population of ${ }^{207} \mathrm{~Pb} /{ }^{206} \mathrm{~Pb}$ ages with mean age of $2683 \pm 23 \mathrm{Ma}$. We interpret this age to be the best estimate for emplacement of the dyke. The discordia lower intercept has an apparent "Pan-African" age. Hf analyses of selected U-Pb spots form single population $\varepsilon \mathrm{Hf}$ at $-0.35 \pm 0.73$.

\subsection{East African Orogen (Handeni block)}

Eight samples were analysed from the Handeni Block, in an area at the heart of the Neoproterozoic East African Orogen (EAO). Six of these were taken from the high-grade "basement" upon which the Wami granulite klippe was overthrust (Fig. 6), and two from the klippe itself (Fig. 7).

\subsubsection{Handeni block "Basement"}

\subsubsection{Sample AMB_108}

$\mathrm{U}-\mathrm{Pb}$ analyses of zircons from this banded felsic garnet granulite are variably discordant with two populations of $<2 \%$ discordant analyses. Discordant analyses predominantly project to the younger of the two concordant populations. The youngest population forms a coherent group of eight analyses with a mean age of $2674 \pm 19 \mathrm{Ma}$, taken as the best estimate for the emplacement of the granulite protolith. The older population ranges in age from 2850 to 3000 Ma but does not form a statistically 
significant single popula0tion. $\mathrm{Hf}$ analyses of selected $\mathrm{U}-\mathrm{Pb}$ spots of the ca. $2.67 \mathrm{Ga}$ population form an array defined by a Lu/Hf slope of 0.015 implying reworking of an older (ca. $3000 \mathrm{Ma}$ ) crustal source consistent with the identified xenocrystic components in the sample.

\subsubsection{Sample AMB_120}

This sample is a coarse-grained granitic orthogneiss made up of quartz, plagioclase, K-feldspar and biotite. $\mathrm{U}-\mathrm{Pb}$ analyses are generally discordant, but lie on a discordia line with an upper intercept at $2693 \pm 40 \mathrm{Ma}$ (taken as a best estimate for the emplacement of the protolith) and an imprecise "PanAfrican" lower intercept. $\mathrm{Hf}$ analyses of selected $\mathrm{U}-\mathrm{Pb}$ spots gave a single population $\varepsilon \mathrm{Hf}$ at $-0.4 \pm 0.7$.

\subsubsection{Sample AMB_14}

$\mathrm{U}-\mathrm{Pb}$ analyses of zircons from this coarse-grained granodioritic orthogneiss (quartz-plagioclase-Kfeldspar-hornblende-biotite) are largely concordant and 10 data points with $<2 \%$ discordance yield a mean age of $2635 \pm 30 \mathrm{Ma}$ interpreted to record the emplacement age of the protolith. $\mathrm{Hf}$ isotopic analyses of selected $\mathrm{U}-\mathrm{Pb}$ spots have $\varepsilon \mathrm{Hf}$ at $-1.7 \pm 0.40$.

\subsubsection{Sample AMB_203}

$\mathrm{U}-\mathrm{Pb}$ zircon analyses of this sample, a melanocratic, hornblende-biotite-bearing granitoid orthogneiss are variably discordant, defining a tightly constrained upper intercept age of $2685 \pm 33 \mathrm{Ma}$ and an imprecise, broadly "Pan-African" lower intercept. $\mathrm{Hf}$ analyses of a selection of U-Pb spots have a single population $\varepsilon \mathrm{Hf}$ at $-1.5 \pm 0.3$. We take the former age as a good estimate of the crystallisation age of the granite.

\subsubsection{Sample AMB_213}

This sample is a dark coarse-grained tonalitic orthogneiss with the mineralogy quartz-plagioclasehornblende-biotite. $\mathrm{U}-\mathrm{Pb}$ analyses are variably discordant but a tightly constrained group of $<2 \%$ discordant analyses yield a mean age of $2652 \pm 29 \mathrm{Ma}$, which is assumed to represent the best age of granite crystallisation. The whole data set lie on a line with an imprecise "Pan-African"-aged lower intercept. $\mathrm{Hf}$ analyses of the most concordant $\mathrm{U}-\mathrm{Pb}$ spots form a single population $\varepsilon \mathrm{Hf}$ at $-2.1 \pm 0.3$.

\subsubsection{Sample F_024}

In this coarse-grained charnockite, core and thin rim phases with complex zoning patterns are revealed in CL images of this coarse-grained two-pyroxene + biotite-bearing charnockite sample. Given the presence of thin growth rims and the potential of ablation spots sampling both rim and core domains, the resulting $\mathrm{U}-\mathrm{Pb}$ analyses of the rims resulted in discordant points with a poorly defined discordia. In the main zircon growth phases, the analyses fall into two populations of concordant analyses at $2717 \pm 29$ and $2670 \pm 29$. These overlap within uncertainty and thus potentially represent a single more scattered population as no correlation between analytical spot and CL-morphology could be documented. In view of this, the two within-error dates are taken to be an estimate of the age of crystallisation of this magmatic charnockite. $\mathrm{Hf}$ analyses of selected $\mathrm{U}-\mathrm{Pb}$ spots within the older age population define a single population $\varepsilon \mathrm{Hf}$ at $-1.29 \pm 0.75$. 


\subsubsection{Handeni block granulite nappes (Wami Complex)}

\subsubsection{Sample D_135}

$\mathrm{CL}$ images of zircons from this coarse-grained orthopyroxene-bearing charnockite reveal oscillatory zoning patterns with faint core alteration and rim overgrowth. U-Pb analyses form a scattered population with a mean age of $674 \pm 21 \mathrm{Ma}$ (Fig. 7) .

\subsubsection{Sample C_182}

C_182 is a coarse-grained granitic orthogneiss which intrudes an extensive body of charnockite, represented by the previous sample. It is composed of quartz, plagioclase, clinopyroxene, garnet and biotite. Zircon CL images reveal complex sector and oscillatory zonation with several apparent growth events; however the $\mathrm{U}-\mathrm{Pb}$ analyses cannot distinguish between the various age zones; rather they have a mean age of $607 \pm 17$. We interpret this age to be the best estimate for the crystallisation of zircon the protolith of the orthogneiss. $\mathrm{Hf}$ analysis revealed scattered analyses potentially representing more than one isotopic composition with a mean of $\varepsilon \mathrm{Hf}$ of $-5.97 \pm 0.51$.

\subsection{Tanzania Craton-Ubendian belt margin (Lupa block)}

Four samples of the Lupa block were analysed and the results are illustrated in Fig. 8.

\subsubsection{Sample ASM_238}

Zircons from this coarse-grained hornblende-biotite granite sample reveal complex CL zoning patterns with dark metamict patterns in the cores and CL bright oscillatory zoned rim phases. Many zircons have apatite inclusions. The $\mathrm{U}-\mathrm{Pb}$ analyses form a variably discordant dataset. $<2 \%$ discordant analyses yield a mean age of $2731 \pm 29 \mathrm{Ma}$, considered to be the crystallisation age, and lie on a line with a poorly-constrained "Pan-African" lower intercept despite having distinct core and rim relationships. $\mathrm{Hf}$ analyses of the most concordant $\mathrm{U}-\mathrm{Pb}$ spots have single population $\varepsilon \mathrm{Hf}$ at $0.81 \pm 0.6$.

\subsubsection{Sample $A S M \_271$}

This sample is a coarse-grained granite composed of quartz, K-feldspar and plagioclase with hornblende and minor garnet. CL images reveal complex zircon zoning patterns with dark metamict structures in the cores and CL-bright homogenous rim growths. $\mathrm{U}-\mathrm{Pb}$ analyses are generally discordant, but $<2 \%$ discordant analyses yield a mean age of $1896 \pm 16 \mathrm{Ma}$, which we interpret to represent the crystallisation age of the granite. The most concordant $\mathrm{U}-\mathrm{Pb}$ spots have single population $\varepsilon \mathrm{Hf}$ at $-4.15 \pm 0.32$.

\subsubsection{Sample ASM_470}

The U-Pb zircon data from this locally migmatitic biotite granite orthogneiss (quartz-K-feldsparplagioclase-biotite) are variably discordant. However, a subset of $<2 \%$ discordant analyses yields a mean age of $1929 \pm 20 \mathrm{Ma}$, which we interpret to represent crystallisation age. $\mathrm{Hf}$ analyses of the most concordant $\mathrm{U}-\mathrm{Pb}$ analytical spots have single population $\varepsilon \mathrm{Hf}$ at $-3.33 \pm 0.34$.

\subsubsection{Sample ASM_364}

This sample is a coarse-grained diorite composed of hornblende and plagioclase with traces of quartz. CL images of zircons from this sample reveal complex oscillatory and sector zoning structures with significant disruption of zonation patterns. Some grains have large apatite(?) rod inclusions. U$\mathrm{Pb}$ analyses are variably discordant with and define a discordia line with an upper intercept of 
$1919 \pm 37 \mathrm{Ma}$ (crystallisation age) and an imprecise "Pan-African" lower intercept. Additionally, this sample displays inheritance $\sim 2800 \mathrm{Ma}$. Hf analyses of selected $\mathrm{U}-\mathrm{Pb}$ spots cluster at $-0.67 \pm 0.70$ with the depleted mantle at 9.8 at $1919 \mathrm{Ma}$. $\mathrm{Hf}$ analysis of an inherited component gave $\varepsilon \mathrm{Hf}$ values of ca. 1, implying that the younger population cannot be explained by reworking of the older felsic $(\mathrm{Lu} / \mathrm{Hf}=0.015)$ or mafic $(\mathrm{Lu} / \mathrm{Hf}=0.022)$ crustal source.

5.4. SE Ubendian belt (Lake Malawi block)

Three samples of the Lake Malawi block were dated and the results are illustrated in Fig. 9.

\subsubsection{Sample ASM_573}

$\mathrm{CL}$ images of zircons from this granitic orthogneiss sample (quartz-plagioclase-K-feldspar-biotiteepidote) reveal complex zoning patterns with partly metamict cores and multiple homogenous rim growths. U-Pb analyses are largely discordant and define a discordia with upper and lower intercepts at $1876 \pm 24$ and $872 \pm 51$ Ma respectively, with the former representing the crystallisation age and the later a metamorphic imprint. Hf analyses of the most concordant $\mathrm{U}-\mathrm{Pb}$ spots of the $1876 \mathrm{Ma}$ population have single population $\varepsilon \mathrm{Hf}$ at $-5.40 \pm 0.33$.

\subsubsection{Sample ASM_590}

ASM_590 is granitic orthogneiss made up of quartz-plagioclase-K-feldspar-hornblende-clinopyroxenebiotite. $\mathrm{CL}$ images of zircon grains have complex zoning patterns with dark oscillatory zoning in the cores and $\mathrm{CL}-$ bright sector-zoned rims. The $\mathrm{U}-\mathrm{Pb}$ analyses are nearly all concordant, such that $23<2 \%$ discordant analyses give a mean age of $1871 \pm 16 \mathrm{Ma}$, here taken as the best estimate of the emplacement age of the granitic protolith. The MSWD of this mean is too high to assume a single statistical population and thus the preferred age should be reported as $\sim 1870 \mathrm{Ma}$. $\mathrm{Hf}$ analyses of selected $\mathrm{U}-\mathrm{Pb}$ spots constitute a single population $\varepsilon \mathrm{Hf}$ at $-4.9 \pm 0.5$.

\subsubsection{Sample ASM_496c}

$\mathrm{CL}$ zircon images from this quartz-feldspar-biotite orthogneiss indicate that two distinct populations of zircons are present with complex zoning patterns. One population is CL-dark and variably metamict, while the second shows CL-bright cores with CL-dark rims. U-Pb analyses fall mostly near the concordia with a range of ages from $\sim 1820 \mathrm{Ma}$ to $1430 \mathrm{Ma}$. A subset of 11 points at $<2 \%$ discordance does not form a single population, although the youngest population yields a mean age of $1435 \pm 15 \mathrm{Ma}$. $\mathrm{Hf}$ analyses of selected U-Pb spots form an array defined by a Lu/Hf slope of 0 implying lead-loss from the oldest analysis $(\sim 1820 \mathrm{Ma})$ to the youngest cluster at $1435 \mathrm{Ma}$. This interpretation should, however, be considered with caution as analyses between these two ages do not form a well constrained discordia. $\varepsilon \mathrm{Hf}$ values from the youngest age cluster define a scattered population centred at $-2.06 \pm 0.66$.

5.5. South Irumide (?) belt (Mgazini block)

Four samples of the Mgazini block were analysed and the results illustrated in Fig. 10.

\subsubsection{Sample $P \_203$}

The U-Pb analyses of detrital zircons recovered from this pure quartzite sample are predominantly $<5 \%$ discordant and have populations with age maxima at 1.1 and $2.7 \mathrm{Ga}$ with other scattered single 
ages. $\mathrm{Hf}$ analyses of selected $\mathrm{U}-\mathrm{Pb}$ spots indicate the involvement of a radiogenically enriched component for the $\sim 1.1 \mathrm{Ga}$ and $\sim 2.6 \mathrm{Ga}$ age populations.

\subsubsection{Sample $P \_204$}

This relatively mafic sample is a two-pyroxene granulitic orthogneiss with the mineralogy plagioclaseclinopyroxene-orthopyroxene, with minor quartz and titanite. Complex zoning in zircons with core and rim phases are revealed by $\mathrm{CL}$ imaging. The $\mathrm{U}-\mathrm{Pb}$ data are discordant, but with reasonably well constrained upper and lower intercepts of $\sim 1800$ and $\sim 1045 \mathrm{Ma}$. A subset of 6 points at $<2 \%$ discordant forms a single population with mean age of $1043 \pm 21 \mathrm{Ma}$. The upper intercept age of $1796 \pm 44 \mathrm{Ma}$ is taken as the best estimate for the emplacement of the orthogneiss protolith, while the subset is interpreted as the age of a metamorphic overprint. Hf analyses of selected $\mathrm{U}-\mathrm{Pb}$ spots of the youngest grains cluster around -8 and older grains have an $\varepsilon \mathrm{Hf}$ signature that projects along a $\mathrm{Lu} / \mathrm{Hf}$ slope of $\sim 0.15$ implying a mixture of two zircon forming events.

\subsubsection{Sample $P_{-} 170$}

$\mathrm{CL}$ images of zircons from this porphyroclastic garnet-biotite-granite orthogneiss sample reveal complex zoning patterns with two phases of zircon. One phase is CL-dark and variably metamict and predominately forms the cores of zircons and the other is CL-bright and predominately forms rims. The $\mathrm{U}-\mathrm{Pb}$ analyses are variably discordant but a subset of 25 points with $<2 \%$ discordance demonstrates a single population with mean age of $1083 \pm 16 \mathrm{Ma}$ and a swath of younger analyses that lie along concordia. This is interpreted to represent a single zircon growth (crystallisation) event at $1083 \mathrm{Ma}$ with lead loss occurring likely within $200 \mathrm{Ma}$ of crystallisation. $\mathrm{Hf}$ analyses of selected $\mathrm{U}_{-}$ $\mathrm{Pb}$ spots have single population $\varepsilon \mathrm{Hf}$ at $-4.1 \pm 0.55$.

\subsubsection{Sample $P_{-} 032$}

The sample is a quartz-plagioclase-hornblende-pyroxene gneiss. Zircon CL images show complex zoning patterns with $\mathrm{CL}$-dark cores and CL-bright rims. U-Pb data points fall along a discrete discordia with upper and lower intercepts at $1984 \pm 35$ and $991 \pm 32$ Ma respectively. A subset of 4 points at $<2 \%$ discordance defines a single population with mean age of $1013 \pm 25 \mathrm{Ma}$. The upper intercept age is taken to reflect crystallisation, while the lower intercept age is considered to represent a Mesoproterozoic metamorphic event. Hf analyses of selected $\mathrm{U}-\mathrm{Pb}$ spots form two arrays defined by $\mathrm{Lu} / \mathrm{Hf}$ slopes of 0.015 and 0 . The former represents a typical $\mathrm{Lu} / \mathrm{Hf}$ evolution path of average continental crust (0.015) and the latter represents lead-loss (0). This implies some of the U-Pb analyses along the discordia represent physical mixtures of the end-member age populations (i.e. those along the 0.015 slope) while the other represents lead-loss along a Lu/Hf slope of 0 .

\section{Bulk-rock Sm-Nd isotope results}

The central Tanzania craton is transected by mafic dyke swarms, one set of which, with a NE trend, is known to be Palaeoproterozoic in age (ca. $1775 \mathrm{Ma}$ ) and interpreted as part of a Large Igneous Province (Mruma et al., 2014). In order to obtain model age data from the dykes, samples from each of the three main dyke trends (NW-SE, N-S, NE-SW) were analysed for Sm-Nd isotopes, along with one supracrustal mafic metavolcanic rock (see Table 1). Bulk-rock $\mathrm{Sm}-\mathrm{Nd}$ isotope data from these samples are summarised inTable 4. $\mathrm{Sm} / \mathrm{Nd}$ ratios lie between 0.15 and 0.19 and are similar to those generally associated with Archaean cratons those are significantly lower than modern mafic lithologies (Hawkesworth et al., 2010). The depleted mantle model ages from these mafic samples do 
not correlate with any of the depleted mantle model ages from the zircon $\mathrm{Hf}$ results reported in the prior section, except for the meatvolcanioc sample FMP_484.

\section{Discussion}

A summary of all the zircon ages obtained in this study is given in Table 5 and Fig. 11 and Fig. 12.

\subsection{Central Tanzania Craton (Dodoma and Singida blocks)}

From the geochronological data, a suite of older granitoids, mainly tonalitic to granodioritic orthogneisses (Dodoma Suite) is recognised with crystallisation ages ranging between $2823 \pm 13$ and $2742 \pm 14 \mathrm{Ma}$. $\varepsilon \mathrm{Hf}$ values cluster around zero to mildly positive (max = ca. 2 ), which is lower than the depleted mantle values of ca. 7 which would be expected, showing that the granitoid melts contained significant amounts of older crustal material in their genesis. A second suite of younger, generally less deformed granitoids (Singida Suite), including unfoliated, coarse-grained potassic syenites and late granitic dykes, is revealed by the zircon data, with emplacement dates from $2727 \pm 31 \mathrm{Ma}$ to $2612 \pm 32 \mathrm{Ma}$. $\varepsilon \mathrm{Hf}$ of zircons in the Singida Suite range from about zero to -4 in the youngest syenite showing, as with the Dodoma Suite, that older crustal material made up a considerable proportion of their parental magmas. Despite this, the zircons in most samples show little evidence of inheritance, though zircon inheritance at ca. 2.8-3.0 Ga, was noted in a few samples. Some samples from both suites that have mainly discordant zircon data show early-Palaeozoic lower intercepts, pointing to possible "Pan-African" disturbance of the system. The ages obtained are the first from the granitoids of the Singida and Dodoma blocks, and are broadly comparable to other dates from elsewhere in the Tanzania Craton (see review by Kabete et al., 2012a and references therein).

One metabasic volcanic sample that is intruded by the Singida Suite was analysed for whole-rock $\mathrm{Sm}-\mathrm{Nd}$ isotopes which yielded $\varepsilon \mathrm{Nd}$ of $3.4 \pm 0.4$ which corresponds to a two-stage depleted mantle model age of $2760 \mathrm{Ma}$ (assuming an eruption age of $\sim 2750 \mathrm{Ma}$ ) (Table 4). This suggests that minor amounts of radiogenically depleted lavas were extruded at this time.

The younger and older magmatic suites, both representing almost $100 \mathrm{Ma}$ of sporadic magmatism are separated by a relatively short (ca. $20 \mathrm{Ma}$ ) period during which supracrustal sedimentary and volcanic rocks were deposited on a basement which included the Dodoma Suite. A pyroclastic schist gave an age of $2725 \pm 36 \mathrm{Ma}$, which is taken as an approximation of the age of explosive volcanism though with a large error. The sample has sub-CHUR $\varepsilon \mathrm{Hf}$, indicating that it is likely not the product of "juvenile" magmatism. Detrital zircons from three psammitic metasedimentary rocks gave largely discordant data, but the most concordant data give approximate maximum depositional ages around $2.7 \mathrm{Ga}$. One quartzite sample (SK_499) yielded largely discordant data, but is important in that it indicates derivation from some very old source rocks. It is likely that apparent age peaks of $<2 \%$ discordant data are spurious and due to $\mathrm{Pb}$-loss as the $\mathrm{Hf}$ data from 'concordant' $\mathrm{U}-\mathrm{Pb}$ analyses lie along a trend reflecting $\mathrm{Lu} / \mathrm{Hf}=0$, typical of $\mathrm{Pb}$-loss. This trend indicates a mantle separation age of $\sim 3.9 \mathrm{Ga}$, i.e. the crustal extraction event for those detrital zircons (and further substantiates a simple 3.7 Ga population). An important inference for this part of the central Tanzania Craton can thus be drawn that the apparently continuous ca. 200 Ma period of granitoid magmatism was punctuated by at least one period of uplift, exhumation, erosion and clastic sedimentation/volcanism, followed by burial and renewed granitic to syenitic magmatism.

In addition, three dolerite dyke samples from each with the three major orientations were analysed for $\mathrm{Sm}-\mathrm{Nd}$ isotopes and have two-stage depleted mantle model ages ranging between $2330 \mathrm{Ma}$ and 
$2075 \mathrm{Ma}$. The age constraints for these dyke swarms are constrained by Mruma et al. (2014) at $\sim 1775 \mathrm{Ma}$ (NE-SW trending dyke swarm). A mafic metavolcanic rock from the cratonic supracrustal sequence gave an Archaean model age.

7.2. Tanzania Craton: eastern margin with the Neoproterozoic East African Orogen (Handeni Block) Seven samples were analysed from the Handeni Block, five samples of granitoid orthogneisses from the "basement" and two samples from the overthrust Wami granulite klippe. The former give ages within uncertainties ranging from $2685 \pm 33$ to $2635 \pm 30 \mathrm{Ma}$. A charnockite sample ( $\left.F \_024\right)$ is interesting in that it contained two populations of magmatic zircons dated at $2717 \pm 29$ and $2670 \pm 29$ Ma; analogous to a similar charnockite from the Msagali area, Mpwapwa District (Thomas et al., 2013), some $150 \mathrm{~km}$ to the east. The younger population is comprised of a mixture of CL-bright rim analyses and zircon cores whereas the older is only large zircon cores. The mixture of younger ages between the CL-bright-rims and cores implies the second zircon growth event was accomplished through not only the growth of new zircon rims, but also the recrystallisation and age resetting of some of the zircon cores. Another sample (ASM-108: banded garnet-bearing felsic granulitic gneiss) gave a crystallisation age of $2674 \pm 19 \mathrm{Ma}$, but with a spectrum of older concordant zircons going back to ca. $3000 \mathrm{Ma}$, which may represent $\mathrm{Pb}$-loss along concordia, in which case the quoted age may be spurious. Four of the granitoid samples provided imprecise Late Neoproterozoic "Pan-African" lower intercept ages, presumably due to isotopic disturbance within the EAO at that time. All the Handeni block basement zircons yielded sub-CHUR \&Hf (up to -2), indicating a significant component of older crust in their genesis.

Two samples from the Wami granulite nappe complex yielded the expected late Neoproterozoic ages of $674 \pm 21$ and $607 \pm 17 \mathrm{Ma}$. Both ages are considered to represent crystallisation ages and place a precise constraint on the maximum age of the thrusting event which emplaced the Wami nappe in the East Africa Orogen over the Neoarchaean basement and further argues for protracted high-thermal gradient metamorphism at this time (see also Maboko and Basu, 1987, Möller et al., 2000 and Bingen et al., 2009). The second sample quoted above gave an $\varepsilon \mathrm{Hf}$ value of ca. -6 (compared to the depleted mantle value of 14.7 at $607 \mathrm{Ma}$ ), demonstrating the involvement of older crustal material in zircon genesis. The age of this sample is similar to that reported in Kröner et al. (1997) for the Mugeba granulite nappes in the Mozambique segment of the East Africa Orogen.

\subsection{Tanzania Craton: southern margin with the Palaeoproterozoic Ubendian-Usagaran orogen (Lupa} and Lake Malawi blocks)

These blocks straddle the projected edge of the Archaean Tanzania Craton and the SE end of the Palaeoproterozoic Ubendian Belt. As such, the data are dominated by Palaeoproterozoic ages. A hornblende granite orthogneiss from the Lupa block gave a crystallisation age of $2731 \pm 29 \mathrm{Ma}$. This is within uncertainty of the Singida Suite typical younger cratonic intrusion and it has a comparable $\varepsilon \mathrm{Hf}$ of about 0 . The crystallisation age is identical to granitoids and orthogneisses dated in the same area by Lawley et al. (2013). The rest of the rocks dated from both blocks are Palaeoproterozoic in age. In the Lupa block, there is apparently no geographic separation of Archaean and Palaeoproterozoic ages, suggesting that the craton edge is probably a complex marginal zone of interleaved cratonic and Ubendian rocks.

The crystallisation ages of the Palaeoproterozoic magmatic rocks from both blocks range from $1929 \pm 20$ to $1871 \pm 16 \mathrm{Ma}$, typical for the Ubendian Belt. Furthermore, the undeformed nature of the granite sample ASM_590, dated at $1896 \pm 16 \mathrm{Ma}$, constrains the NE edge of the Ubendian orogenic front in this area. Although zircon in this sample shows distinct core and rim CL-zonation, the difference in age of crystallisation this represents is unresolvable (ig . 9). The Ubendian-Usagaran 
event spans a period of around $200 \mathrm{Ma}(2000-1800 \mathrm{Ma})$, punctuated by subduction of oceanic lithosphere recorded in eclogites, collisions/accretions, high-grade crustal thickening metamorphism and calc-alkaline magmatism (e.g. Lenoir et al., 1994; Möller et al., 1995 and Boniface et al., 2012). All samples have slightly negative $\varepsilon \mathrm{Hf}$ (ca. -1 to -5 ), showing that they were derived from melts with a significant contribution of older crustal, material, presumably from the Tanzania Craton. The most south-easterly sample from the two blocks gave a spectrum of near-concordant Palaeo- to Mesoproterozoic ages, with a group of $<2 \%$ discordant grains giving an age of $1436 \pm 5 \mathrm{Ma}$, suggesting an incoming influence from the Mesoproterozoic belt which occurs to the SE, in southernmost Tanzania (Kröner et al., 2003, Sommer et al., 2005, Thomas et al.,

2014 and Hauzenberger et al., 2014). Early Mesoproterozoic ages 1.39-1.36 Ga are common in the NW Ubendian Belt proximal to the NE Kibaran Belt (Karagwe-Ankolean Belt) and are associated with the intrusion of mafic ultramafic layered igneous complex of the Kapalagulu-Kabanga-Musongati alignment (e.g. Maier et al., 2007). This age is also very similar to the maximum age of $1434 \pm 14 \mathrm{Ma}$ for the mature fluvial quartzites of the Kasama Formation, a discrete succession in the Bangweulu Block of Eastern Zambia, situated about $250 \mathrm{~km}$ east of the study area (De Waele and Fitzsimons, 2007).

\subsection{Mesoproterozoic margin (Mgazini block)}

This previously unsurveyed region lies along the SE projection of the Palaeoproterozoic Ubendian Belt and approaching a terrane of known Mesoproterozoic crust; the eastern prolongation of the south Irumide belt (Kröner et al., 2003, Sommer et al., 2005, Thomas et al., 2014 and Hauzenberger et al., 2014). The new data document this transitional nature. Two high-grade orthogneisses give U-Pb discordia with Palaeoproterozoic (1984 \pm 35 and $1796 \pm 46 \mathrm{Ma}$ ) upper intercept and Mesoproterozoic (1013 $\pm 25 \mathrm{Ma}$ and $1043 \pm 21 \mathrm{Ma}$ ) lower intercept ages, respectively. Although samples P_170 and P_032 display distinct zircon core and rim CL-zonation, only the zonation in sample P_032 has resolvably different core and rim $\mathrm{U}-\mathrm{Pb}$ ages ( $\underline{\text { Fig. 10 })}$. These are interpreted to represent Palaeoproterozoic (Ubendian) igneous rocks which were affected by Mesoproterozoic (Irumide) high grade metamorphism. These samples show a range of sub-CHUR $\varepsilon \mathrm{Hf}$ values indicating an older crustal component. One orthogneiss sample gave an age of $1083 \pm 16 \mathrm{Ma}$, considered to be the crystallisation age and thus represents South Irumide magmatism. The sample contained no older inherited zircons, but the negative $\varepsilon \mathrm{Hf}$ values obtained show involvement of older crustal material in its genesis. These findings are consistent with other works (e.g. Kröner et al., 2003), who concluded that similar Mesoproterozoic igneous rocks to the SE of the study area (Msasi region) were derived from the remelting of Archaean continental crust.

A quartzite sample from this region (P_203) contains a number of craton-derived zircons at ca. $2.7 \mathrm{Ga}$, a small amount of Palaeoproterozoic (ca. $2 \mathrm{Ga}$ ) detritus, but the bulk of the grains lie within 1100-1000 Ma, which may approximate to the age of deposition. This implies that the quartzite, part of a metasedimentary sequence including marbles represents a post-Irumide basinal sequence.

Mesoproterozoic high grade metamorphic reworking of the Ubendian Basement rocks between $1170 \mathrm{Ma}$ and $1110 \mathrm{Ma}$ is similarly recorded in NW Ubendian Belt, interpreted as the effect of the neighbouring South Irumide Belt to the west (e.g. Boniface et al., 2014).

\section{Regional implications}

The data presented here have considerable implications for the evolution of the crust of the southern half of Tanzania. 


\subsection{Tanzania "metacraton"?}

The first important observation is the zircon isotopic data from all samples, whether from the Tanzania Craton or the surrounding mobile belts, show evidence of derivation from older crustal material, as evidenced by consistent sub-CHUR $\varepsilon \mathrm{Hf}$ values that lie along a single crustal evolution trend and backed-up by zircon inheritance, mainly Neoarchaean, in many samples. This implies that not only has the craton a consistently older pre-history, but that it also possibly represents a "metacraton" (sensu Liégeois et al., 2013) whereby an older core as represented by the Singida and Dodoma blocks of our study area, is surrounded by a vast marginal terrane of re-working during subsequent accretionary orogeneses. This is exemplified by the SE and southern "inboard" margin in the Palaeoproterozoic (Ubendian-Orogeny) of the Lupa and Lake Malawi blocks, the southern "outboard" Mesoproterozoic (Irumide) margin in the Mgazini block and the eastern Neoproterozoic (East African Orogen) margin of the Handeni block.

The metacraton hypothesis only holds if the surrounding reworked crust was originally part of a larger contiguous cratonic entity - a situation concluded as the most likely in Tanzania by some authors (e.g. Vogt et al., 2006). However others, such as Collins et al. (2004), note that the slightly younger detrital zircon ages of 2400-2640 Ma they reported from the Usagaran orogen, ca. $100 \mathrm{~km}$ south of the Dodoma block, were similar to ages from the Antananarivo Craton of Madagascar, which may have lain adjacent to East Africa in the late Palaeoproterozoic. This hypothesis suggests that at least some of the Archaean crust adjacent to the Tanzania Craton may not be reworked, but be allochthonous segments of (an)other, unrelated cratonic block(s), which collided with the Tanzania Craton.

On the SW side of the Ubendian belt, the Bangweulu Block and Irumide Belt of Zambia also record long histories of crustal recycling of Archaean basement. The former has been described as a metacraton (De Waele et al., 2006), but these terranes might equally either represent reworking of autochthonous Tanzania "Metacraton" or segments of other, juxtaposed, exotic Archaean blocks. Clearly further work is needed to resolve these issues which would involve detailed "fingerprinting" of the precise origins of the reworked Archaean crust of Tanzania and environs.

\subsection{Palaeoproterozoic to Mesoproterozoic complexity}

As pointed out by Hauzenberger et al. (2014) southern Tanzania represents a complex area where several mobile belts converge around the southern edge of the Tanzania Craton in areas that are still quite remote and difficult to access for detailed fieldwork. Anticlockwise from SE Tanzania, the NWSE striking Palaeoproterozoic Ubendian Belt is shown to pass through the Lupa and Lake Malawi blocks, proving a link to the final SE termination of the belt along the eastern shores of Lake Malawi in Niassa Province in NW Mozambique (the Ponte Messuli Complex; Bingen et al., 2009).

Mesoproterozoic belts in this part of Africa include the SW-NE trending Irumide (re-worked older crust) or South Irumide (more juvenile crust) belts in Zambia (e.g. De Waele et al., 2006) which approach southern Tanzania from the west. In the south, in NE Mozambique and southern Tanzania, the northern extensions of the Unango and Marrupa Complexes are recorded.

\subsection{Isotopic reworking of the metacraton}

The $\varepsilon \mathrm{Hf}$ data that lie along a single trajectory corresponding to a $\mathrm{Lu} / \mathrm{Hf}$ ratio of 0.028 . This extremely high Lu/Hf ratio is indicative of a mafic to ultramafic parent rock (Kinny and Maas, 2003 and Harrison et al., 2008). High Lu/Hf ratios have also been reported in other Archaean cratonic cores (Zeh et al., 2007 and Zeh et al., 2014) and seem to be the hallmark of early cratonisation when the proportion of radiogenically depleted to enriched crust was significantly higher than in the Proterozoic and Phanerozoic Eons. It is possible that this trend does not actually represent an evolution trajectory, but 
represents a consistent mixture of radiogenically depleted and enriched $\mathrm{Hf}$ for $\sim 3$ billion years (Fig. 13).

\section{Summary and conclusions}

The main conclusions of this study can be summarised as follows:

The Neoarchaean geochronology of the central Tanzania Craton (Singida and Dodoma blocks) is essentially the same, suggesting that they form a contiguous part of the Tanzania Craton which is volumetrically dominated by granitoid plutons.

Episodic granitoid plutonism and deposition of low-grade volcano-sedimentary rocks (greenstones) in the Singida and Dodoma blocks spans a period of about 200 Ma with the oldest granitic orthogneisses dated at ca. $2820 \mathrm{Ma}$ and the youngest alkaline syenite plutons dated at ca. $2610 \mathrm{Ma}$. This is consistent with a (seemingly quite short) period of uplift, exhumation, erosion, clastic sedimentation, and volcanism, followed by burial and renewed granitic to syenitic magmatism.

The older granitoids and orthogneisses (Dodoma Suite) were emplaced between ca. 2.82 and 2.74 Ga and formed the basement upon which the supracrustal rocks were deposited, a pyroclastic volcanic rock of which gave an age of ca. $2.73 \mathrm{Ga}$. Detrital zircons from psammitic rocks provide maximum depositional ages of around $2.74 \mathrm{Ga}$, with older detritus between ca. 2.8 and $3.0 \mathrm{Ga}$.

Post-supracrustal magmatism is represented by a suite of granites, syenites and post-tectonic granitoid dykes (Singida Suite) between ca. 2.72 and $2.61 \mathrm{Ga}$.

The early, pre-supracrustal magmatic rocks (orthogneisses) underwent a ductile foliation event, whereas the post-supracrustal plutonic rocks are essentially undeformed.

In the Handeni block, in the heart of the East African Orogen, all rocks, apart from the rocks of the overthrust Neoproterozoic granulite nappes, have Neoarchaean protolith ages within a narrow range of ages between 2710 and $2630 \mathrm{Ma}$, identical to (but more restricted than) the ages of the post-supracrustal rocks of the Tanzania Craton. These rocks comprise the "Western granulites" of the literature (e.g. Fritz et al., 2009). These rocks show poorly-defined Ediacaran "Pan-African" isotopic disturbance. Within the sample set, a Neoarchaean charnockite contained two populations of apparently igneous zircons dated at ca. 2710 and $2670 \mathrm{Ma}$ in an analogous situation to the Msagali charnockite some $150 \mathrm{~km}$ to the east (Thomas et al., 2013); 
The overthrust granulites of the Wami Complex nappe have been dated between ca. 605 and $670 \mathrm{Ma}$, coeval with previous dates of the "Eastern Granulites" of eastern Tanzania and the Cabo Delgado granulite nappes of adjacent NE Mozambique. However, with $\varepsilon \mathrm{Hf}$ of ca. -6 , the Wami nappe, at least does not represent a juvenile Neoproterozoic addition to the crust and rather represents reworking of the Tanzania meta-craton. This is contrary to previous assertions in other granulite complexes of eastern Tanzania.

One sample of an orthogneiss from the Lupa Block is dated at ca. $2730 \mathrm{Ma}$, and clearly belongs to the Tanzania Craton. Other granitoid samples from the Lupa Block show Ubendian (ca. $1920 \mathrm{Ma}$ ) crystallisation ages. These ages, support previous work (e.g. Lawley et al., 2013) that the Archaean-Palaeoproterozoic boundary is not a simple one, with geographic distribution of the ages suggesting a complex, probably tectonic, interleaving of craton and mobile belt. Negative $\varepsilon \mathrm{Hf}$ values from the Ubendian granitoids $(-1$ to -4$)$ show that older crust was involved in their genesis.

To the south, outcrops by the northern tip of Lake Malawi, mark the SE continuation of the Ubendian belt, albeit with slightly younger ages of igneous rocks (ca. 1870-1900 Ma) and similarly negative $\varepsilon \mathrm{Hf}(-2$ to -5$)$. These rocks form a link with granitoids from the Songea area along strike to the SE, and the Ponte Messuli Complex, in northern Mozambique.

Rocks from the remote Mgazini area to the south east gave Palaeoproterozoic, Ubendian protolith ages of ca. 1980-1800 Ma. These rocks have undergone Late Mesoproterozoic (Irumide) high grade metamorphism between 1015 and $1040 \mathrm{Ma}$. One sample gave a crystallisation age of ca. 1080 Ma showing that Mesoproterozoic plutonic rocks intruded the Ubendian protoliths of this area. This provides a link with known Mesoproterozoic crust to the east in SE Tanzania and NE Mozambique, giving a valuable, hitherto unknown constraint on the distribution of ca. $1 \mathrm{Ga}$ crust in SE Africa, and with a possible link with the South Irumide Belt further west.

$\mathrm{Hf}$ data from concordant analyses of detrital zircons in one sample from the Dodoma block (SK_499) lie along a Pb-loss trend $(\mathrm{Lu} / \mathrm{Hf}=0)$, extending back to $\sim 3.9 \mathrm{Ga}$, probably the crustal extraction event of the zircons. Furthermore, the compiled $\mathrm{Hf}$ from all igneous samples from the entire sample area show an evolution trend extending back to the same mantle extraction age. This implies the entire Tanzanian crust sampled in this study can be traced back to a single mantle extraction event at $3.9 \mathrm{Ga}$ with parent material composed of a depleted, mafic source with a very high Lu/Hf ratio.

The data from this study help to define the margins of the stable nucleus of the Tanzania Craton which is surrounded to the west, south and east by a wide reworked envelope, almost as large in extent as the stable nucleus itself. Providing that the vast zones of reworked 
Archaean rocks are essentially autochthonous (i.e. they are not composed of various, juxtaposed exotic Archaean terranes), The Tanzania Craton conforms well to the definition of a "meta-craton", with an old, stable core and a wide, strongly re-worked rim.

\section{Acknowledgements}

The authors thank Adrian Wood and Vanessa Pashley for assistance with in the U-Pb analyses. The technical and support staff of GST are thanked for their help and support during the long field campaigns in 2013. We are deeply indebted to very detailed and critical reviews by Bernard Bingen and Bert De Waele.

\section{References}

Bingen, B., Jacobs, J., Viola, G., Henderson, I.H., Skår, Ø., Boyd, R., Thomas, R.J., Solli, A., Key, R.M., Daudi, E.X., 2009. Geochronology of the Precambrian crust in the Mozambique Belt of NE Mozambique, and implications for Gondwana assembly. Precambrian Res. 170, 231-255.

Boniface, N., Schenk, V., 2012. Neoproterozoic eclogites in the Paleoproterozoic Ubendian Belt of Tanzania: evidence for a Pan-African suture between the Bangweulu Block and the Tanzania Craton. Precambrian Res. 208-211, 72-89. 66 R.J. Thomas et al. / Precambrian Research 277 (2016) 47-67 Boniface, N., Schenk, V., Appel, P., 2012. Paleoproterozoic eclogites of MORB-type chemistry and three Proterozoic orogenic cycles in the Ubendian Belt (Tanzania): evidence from monazite and zircon geochronology, and geochemistry. Precambrian Res. 192-195, 16-33.

Boniface, N., Schenk,V.,Appel, P., 2014. Mesoproterozoic high-grade metamorphism in pelitic rocks of the northwestern Ubendian Belt: implication for the extension of the Kibaran intra-continental basins to Tanzania. Precambrian Res. 249, 215-228.

Collins, A.S., Reddy, S.M., Buchan, C., Mruma, A., 2004. Temporal constraints on Palaeoproterozoic eclogite formation and exhumation (Usagaran Orogen, Tanzania). Earth Planet. Sci. Lett. 224, 175192.

Cutten, H., Johnson, S.P., Waele, B.D., 2006. Protolith ages and timing of metasomatism related to the formation of Whiteschists at Mautia Hill, Tanzania: implications for the assembly of Gondwana. J. Geol. 114, 683-698.

Daly, M.C., 1988. Crustal shear zones in central Africa: a kinematic approach to Proterozoic tectonics. Episodes 11, 5-11.

De Waele, B., Liégeois, J.-P., Nemchin, A.A., Tembo, F., 2006. Isotopic and geochemical evidence of Proterozoic episodic crustal reworking within the Irumide Belt of south-central Africa, the southern metacratonic boundary of an Archaean Bangweulu Craton. Precambrian Res. 148, 225-256.

De Waele, B., Fitzsimons, I.C.W., 2007. The nature and timing of Palaeoproterozoic sedimentation at the southeastern margin of the Congo Craton; zircon $\mathrm{U}-\mathrm{Pb}$ geochronology of plutonic, volcanic and clastic units in northern Zambia. Precambrian Res. 159, 95-116. 
Eades, N.W., Reeves, W.H., 1938. Explanation of the geology of Degree Sheet No 29 (Singida). Department of Lands and Mines, Tanganyika Territory, Dar es Salaam, 62p.

Fisher, C.M., Hanchar, J.M., Samson, S.D., Dhuime, B., Blichert-Toft, J., Vervoort, J.D., Lam, R., 2011. Synthetic zircon doped with hafnium and rare earth elements: a reference material for in situ hafnium isotope analysis. Chem. Geol. 286, 32-47.

Fritz, H., Tenczer, V., Hauzenberger, C.A., Wallbrecher, E., Hoinkes, G., Muhongo, S., Mogessie, A., 2005. Central Tanzanian Tectonic Map (CTTM): a step forward to decipher proterozoic structural events in the East African orogen. Tectonics 24, TC6013.

Fritz, H., Tenczer, V., Hauzenberger, C., Wallbrecher, E., Muhongo, S., 2009. Hot granulite nappestectonic styles and thermal evolution of the Proterozoic granulite belts in East Africa. Tectonophysics 477, 160-173.

Harpum, J.R., 1958. 1:125,000 Geological Map ofthe Kipengere Quarter Degree Sheet (79NW). Geological Survey Department, Dodoma.

Harrison, T.M., Schmitt, A.K., McCulloch, M.T., Lovera, O.M., 2008. Early 4.5 Ga formation of terrestrial crust: Lu-Hf,

180, and Ti thermometry results for Hadean zircons. Earth Planet. Sci. Lett. 268, 476-486.

Hauzenberger, C.A., Tenczera, V., Bauernhofera, A., Fritz, H., Klötzlib, U., Kosler, ` J., Wallbrecher, E., Muhongo, S., 2014. Termination of the Southern Irumide Belt in Tanzania: zircon U/Pb geochronology. Precambrian Res. 255, 144-162.

Hawkesworth, C.J., Dhuime, B., Pietranik, A., Cawood, P., Kemp, A.A.I., Storey, C.D., 2010. The generation and evolution of the continental crust. J. Geol. Soc. London 167, 229-248, http://dx.doi.org/10.1144/0016-76492009-072 (Review).

Hiess, J., Condon, D.J., McLean, N., Noble, S.R., 2012. 238U/235U systematics in terrestrial uraniumbearing minerals. Science 335, 1610-1614, http://dx.doi.org/10. 1126/science.1215507.

Horstwood, M.S.A., Foster, G.L., Parrish, R.R., Noble, S.R., Nowell, G.M., 2003. Common-Pb corrected in situ U-Pb accessory mineral geochronology by LAMC-ICP-MS. J. Anal. At. Spectrom. 18, 837.

Jackson, S.E., Pearson, N.J., Griffin,W.L., Belousova, E.A., 2004. The application of laser ablationinductively coupled plasma-mass spectrometry to in situ U-Pb zircon geochronology. Chem. Geol. 211, 47-69.

Johnson, S.P., Cutten, H.N.C., Muhongo, S., De Waele, B., 2003. Neoarchaean magmatism and metamorphism of the western granulites in the central domain of the Mozambique belt, Tanzania, $\mathrm{U}-\mathrm{Pb}$ shrimp geochronology and PT estimates. Tectonophysics 375, 125-145.

Kabete, J.M., McNaughton, N.J., Groves, D.I., Mruma, A.H., 2012a. Reconnaissance SHRIMP U-Pb zircon geochronology of the Tanzania Craton: evidence for Neoarchean granitoid-greenstone belts 
in the Central Tanzania Region and the Southern East African Orogen. Precambrian Res. 216-219, 232-266.

Kabete, J.M., Gorves, D.I., McNaughton, N.J., Mruma, A.H., 2012b. A new tectonic and temporalframework for the TanzanianShield:implications for goldmetallogeny and undiscovered endowment. Ore Geol. Rev. 48, 88-124.

Kazimoto, E.O., Schenk, V., Berndt, J., 2014. Neoarchean and Paleoproterozoic crust formation in the Ubendian Belt of Tanzania: insights from zircon geochronology and geochemistry. Precambrian Res. 252, 119-144.

Kazimoto, E.O., Schenk, V., Appel, P., 2015. Granulite-facies metamorphic events in the northwestern Ubendian Belt of Tanzania: implications for the Neoarchean to Paleoproterozoic crustal evolution. Precambrian Res. 256, 31-47.

Kinny, P.D., Maas, R., 2003. Lu-Hf and Sm-Nd isotope systems in zircon. In: Hanchar, J.M., Hoskin, P.W.O. (Eds.), Zircon. The Geological Society of America, Washington, USA, pp. 327-341

Kröner, A., Sacchi, R., Jaeckel, P., Costa, M., 1997. Kibaran magmatism and PanAfrican granulite metamorphism in northern Mozambique: single zircon ages and regional implications. J. Afr. Earth Sci. 25, 467-484.

Kröner, A., Muhongo, S., Hegner, E., Wingate, M.T.D., 2003. Single zircon geochronology and Nd isotopic systematics of Proterozoic high grade rocks from the Mozambique belt of southern Tanzania (Masasi area): implications for Rodinia and Gondwana assembly. J. Geol. Soc. London 160, 745-757.

Lawley, C.J.M., Selby, D., Condon, D.J., Horstwood,M.S.A.,Millar,I., Crowley, Q., Imber, J., 2013. Lithogeochemistry, geochronology and geodynamic setting of the Lupa Terrane, Tanzania: implications for the extent of the Archean Tanzanian Craton. Precambrian Res. 231, 174-193.

Lenoir, J.L., Liegeois, J.-P., Theunissen, K., Klerkx, J., 1994. The Paleoproterozoic Ubendian shear belt in Tanzania: geochronology and structure. J. Afr. Earth Sci. 19, 169-184.

Liégeois, J.-P., Abdelsalam, M.G., Ennih, N., Ouabadi, A., 2013. Metacraton: nature, genesis and behaviour. Gondwana Res. 23, 220-237. Ludwig, K.R., 2012. User's Manual for a Geochronological Toolkit for Microsoft Excel. Berkeley Geochronol. Cent. Spec. Publ., pp. 1-75.

Maboko, M.A., 2000. Nd and Sr isotopic investigation of the Archean-Proterozoic boundary in north eastern Tanzania: constraints on the nature of Neoproterozoic tectonism in the Mozambique Belt. Precambrian Res. 102, 87-98.

Maboko, M.A.H., 2001. Dating post-metamorphic cooling of the Eastern Granulites in the Mozambique Belt of Northern Tanzania using the garnet Sm-Nd method. Gondwana Res. 4, 329336.

Maboko, M.A.H., Basu, N.K., 1987. The geochemistry of mafic and ultramafic rocks in the Wami River granulite complex, central coastal Tanzania. J. Afr. Earth Sci. 6, 845-850. 
Maier, W.D., Peltonen, P., Livesey, T., 2007. The ages of the Kabanga north and Kapalagulu intrusions, western Tanzania: a reconnaissance study. Econ. Geol. 102 (1), 147-154.

Manya, S., Maboko, M.A.H., 2008. Geochemistry and geochronology of Neoarchaean volcanic rocks of the Iramba-Sekenke greenstone belt, central Tanzania. Precambrian Res. 163, 265-278.

Möller, A., Appel, P., Mezger, K., Schenk, V., 1995. Evidence for a 2 Ga subduction zone: eclogites in the Usagaran Belt of Tanzania. Geology 23, 1067-1070.

Möller, A., Mezger, K., Schenk, V., 2000. U-Pb dating of metamorphic minerals: PanAfrican metamorphism and prolonged slow cooling of high pressure granulites in Tanzania, East Africa. Precambrian Res. 104, 123-146.

Mruma, A.H., Semkiwa, P., Temu, E.B., Minde, A.B., 2009. Updated stratigraphy of Tanzania and related mineral recourses potential. Tanzanian J. Earth Sci. 1, 2-28.

Mruma, A.H., Ernst, R.E., Soderland, U., 2014. Evidence for ca. 1775 Ma large igneous province (LIP) in the Tanzanian Craton. In: Abstract, 25th Colloquium of African Geology, Dar-es-Salaam, Tanzania, p. 9.

Muhongo, S., Kroner, A., Nemchin, A.A., 1999. Zircon ages from granulite facies rocks in the Mozambique Belt of Tanzania and implications for Gondwana assembly. J. Geol. 109, 171-189.

Muhongo, S., Tuisku, P., Mnali, S., Temu, E., Appel, P., Stendal, H., 2002. High-pressure granulitefacies metagabbros in the Ubendian Belt of SW Tanzania. Preliminary petrography and P-T estimates. J. Afr. Earth Sci. 34, 279-285.

Nowell, G.M., Parrish, R.R., 2001. Simultaneous acquisition of isotope compositions and parent/daughter ratios by non-isotope dilution solution-mode Plasma ionisation Multi-collector Mass Spectrometry (PIMMS). In: Tanner, S.D., Holland, J.G. (Eds.), Plasma Source Mass Spectrometry. The New Millennium. Royal Society of Chemistry, London, pp. 298-310.

Pinna, P., Muhongo, S., Mcharo, B.A., Le Goff, E., Deschamps, Y., Ralay, F., Milesi, J.P., 2004. Geology and Mineral map of Tanzania at 1:2 000 000. Bureau de Reserches Geologique et Minieres-University of Dar-es-Salaam-Geological Survey of Tanzania.

Schoene, B., Crowley, J.L., Condon, D.J., Schmitz, M.D., Bowring, S.A., 2006. Reassessing the uranium decay constants for geochronology using ID-TIMS U-Pb data. Geochim. Cosmochim. Acta 70, 426445 .

Sláma, J., Kosler, ` J., Condon, D.J., Crowley, J.L., Gerdes, A., Hanchar, J.M., Horstwood, M.S.A., Morris, G.A., Nasdala, L., Norberg, N., Schaltegger, U., Schoene, B., Tubrett, M.N.,Whitehouse, M.J., 2008. Plesovice zircon-a new natural reference material for $\mathrm{U}-\mathrm{Pb}$ and $\mathrm{Hf}$ isotopic microanalysis. Chem. Geol. 249, 1-35.

Sommer, H., Kröner, A., 2013. Ultra-high temperature granulite-facies metamorphic rocks from the Mozambique belt of SW Tanzania. Lithos 170-171, 117-143. 
Sommer, H., Kröner, A., Hauzenberger, C., Muhongo, S., 2005. Reworking of Archaean and Palaeoproterozoic crust in the Mozambique belt of central Tanzania as documented by SHRIMP zircon geochronology. J. Afr. Earth Sci. 43, 447-463.

Spencer, C.J., Cawood, P.A., Hawkesworth, C.J., Prave, A.R., Roberts, N.M.W., Horstwood, M.S.A., Whitehouse, M.J., 2015. Generation and preservation of continental crust in the Grenville Orogeny. Geosci. Front. 6, 357-372, http://dx.doi. org/10.1016/j.gsf.2014.12.001.

Tanaka, T., Togashi, S., Kamioka, H., Amakawa, H., Kagami, H., Hamamoto, T., Yuhara, M., Orihashi, Y., Yoneda, S., Shimizu, H., Kunimaru, T., Takahashi, K., Yanagi, T., Nakano, T., Fujimaki, H., Shinjo, R., Asahara, Y., Tanimizu, M., Dragusanu, C., 2000. JNdi-1: a neodymium isotopic reference in consistency with LaJolla neodymium. Chem. Geol. 168, 279-281, http://dx.doi.org/10.1016/S00092541(00)00198-4.

Tenczer, V., Hauzenberger, C.A., Fritz, H., Hoinkes, G., Muhongo, S., Klötzli, U., 2011. The P-TX(fluid) evolution of meta-anorthosites in the Eastern Granulites, Tanzania. J. Metamorph. Geol. 29, 537-560.

Thomas, R.J., Roberts, N.M.W., Jacobs, J., Bushi, A.M., Horstwood, M.S.A., Mruma, A., 2013. Structural and geochronological constraints on the evolution of the eastern margin of the Tanzania Craton in the Mpwapwa area, central Tanzania. Precambrian Res. 224, 671-689.

Thomas, R.J., Bushi, A.M., Roberts, N.M.W., Jacobs, J., 2014. Geochronology of granitic rocks from the Ruangwa region, southern Tanzania - links with NE Mozambique and beyond. J. Afr. Earth Sci. $100,70-80$.

Vermeesch, P., 2012. On the visualisation of detrital age distributions. Chem. Geol. 312-313, 190194.

Vogt, M., Kröner, A., Poller, U., Sommer, H., Muhongo, S., Wingate, M.T.D., 2006. Archaean and Palaeoproterozoic gneisses reworked during a Neoproterozoic (Pan-African) high-grade eventin the Mozambique belt of East Africa: structural relationships and zircon ages from the Kidatu area, central Tanzania. J. Afr. Earth Sci. 45, 139-155.

Wade, F.B., Oates, F., 1938. An explanation of Degree Sheet No. 52 (Dodoma). Short paper of the Geological Division, Department of Land and Mines, Tanganyika, 17, 58p.

Wiedenbeck, M., Allé, P., Corfu, F., Griffin, W.L.W., Meier, M., Oberli, F., Quadt, A., Von Roddick, J.J.C., Spiegel, W., Alle, P., Von Quart, A., 1995. Three natural zircon standards for U-Th-Pb, Lu-Hf, trace element, and REE analyses. Geostandards Newslett. 19, 1-23.

Zeh, A., Gerdes, A., Klemd, R., Barton, J.M., 2007. Archaean to Proterozoic crustal evolution in the central zone of the Limpopo Belt (South Africa-Botswana): constraints from combined U-Pb and Lu$\mathrm{Hf}$ isotope analyses of zircon. J. Petrol. 48, 1605-1639. 
Zeh, A., Stern, R.A., Gerdes, A., 2014. The oldest zircons of Africa-their U-Pb-Hf-O isotope and trace element systematics, and implications for Hadean to Archean crust-mantle evolution. Precambrian Res. 241, 203-230. 
Figure 1: Geotectonic map of Tanzania with the studied areas highlighted and showing the sample sites.

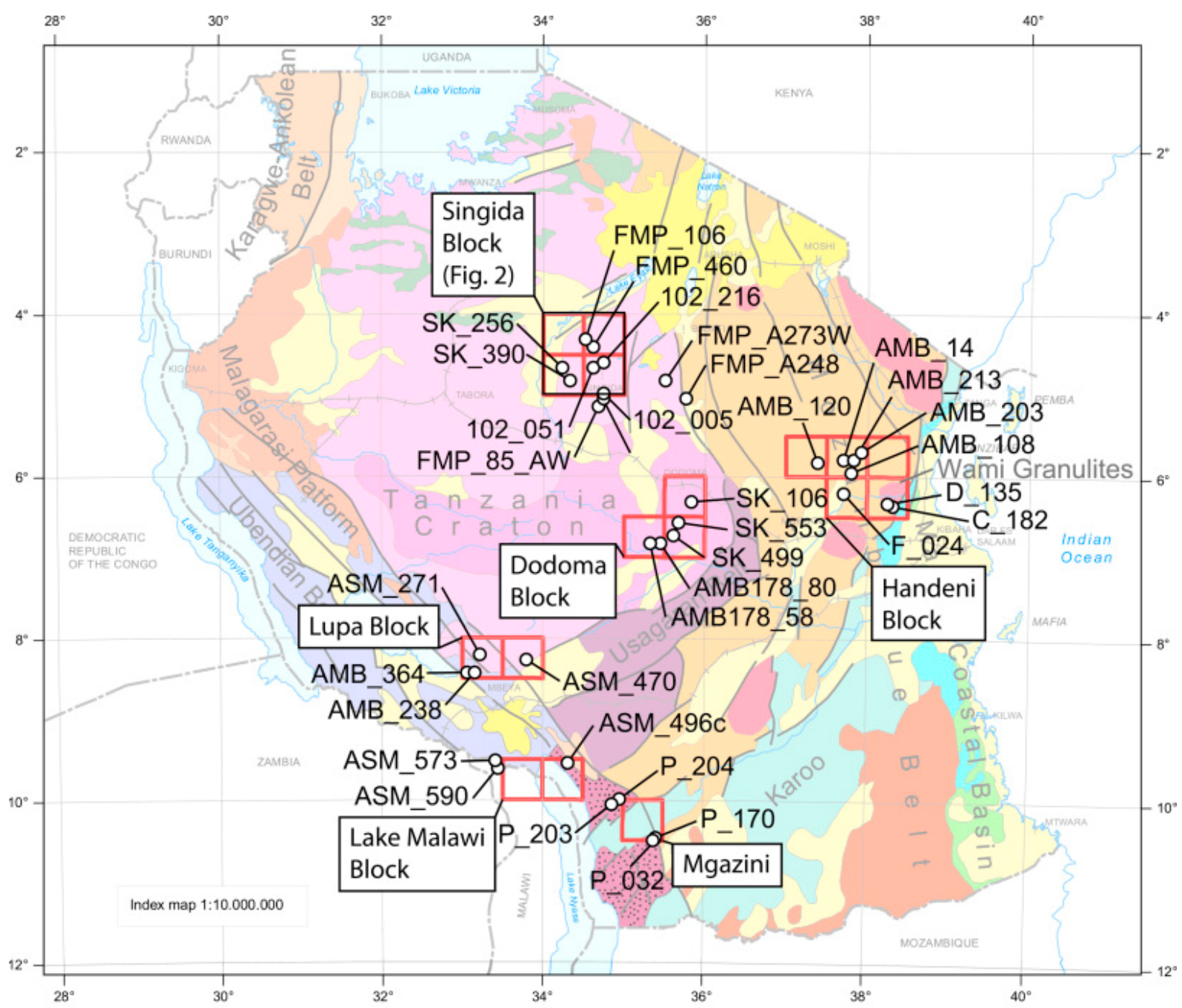

Cenozoic basin and coastal sediments

Cenozoic volcanic rocks

Cretaceous marine sediments

Jurassic marine sediments

Triassic-Upper Carboniferous (Karoo) sedimentary rocks including Permian coals

Neoproterozoic Malagarasi Supergroup

Neoproterozoic granulite complexes (Mozambique Belt) Mesoproterozoic Belt with Neoproterozoic "Pan-African" overprint (Mozambique Belt)
Mesoproterozoic Kibaran Karagwe-Ankolean Belt

\section{Mesoproterozoic Bukoba Group}

Palaeoproterozoic Ubendian Belt with Mesoproterozoic overprint

\pm Neoproterozoic "Pan-African" overprint

Palaeoproterozoic Usagaran Belt

Palaeoproterozoic Ubendian Belt

Mainly Neoarchaean rocks with Neoproterozoic overprint

(Mozambique Belt)

Neoarchaean, Kavirondian and Nyanzian supergroups

Neoarchaean greenstone belts

Meso-Neoarchaean Dodoma Complex

Figure 2: Simplified geology of the Singida block. 


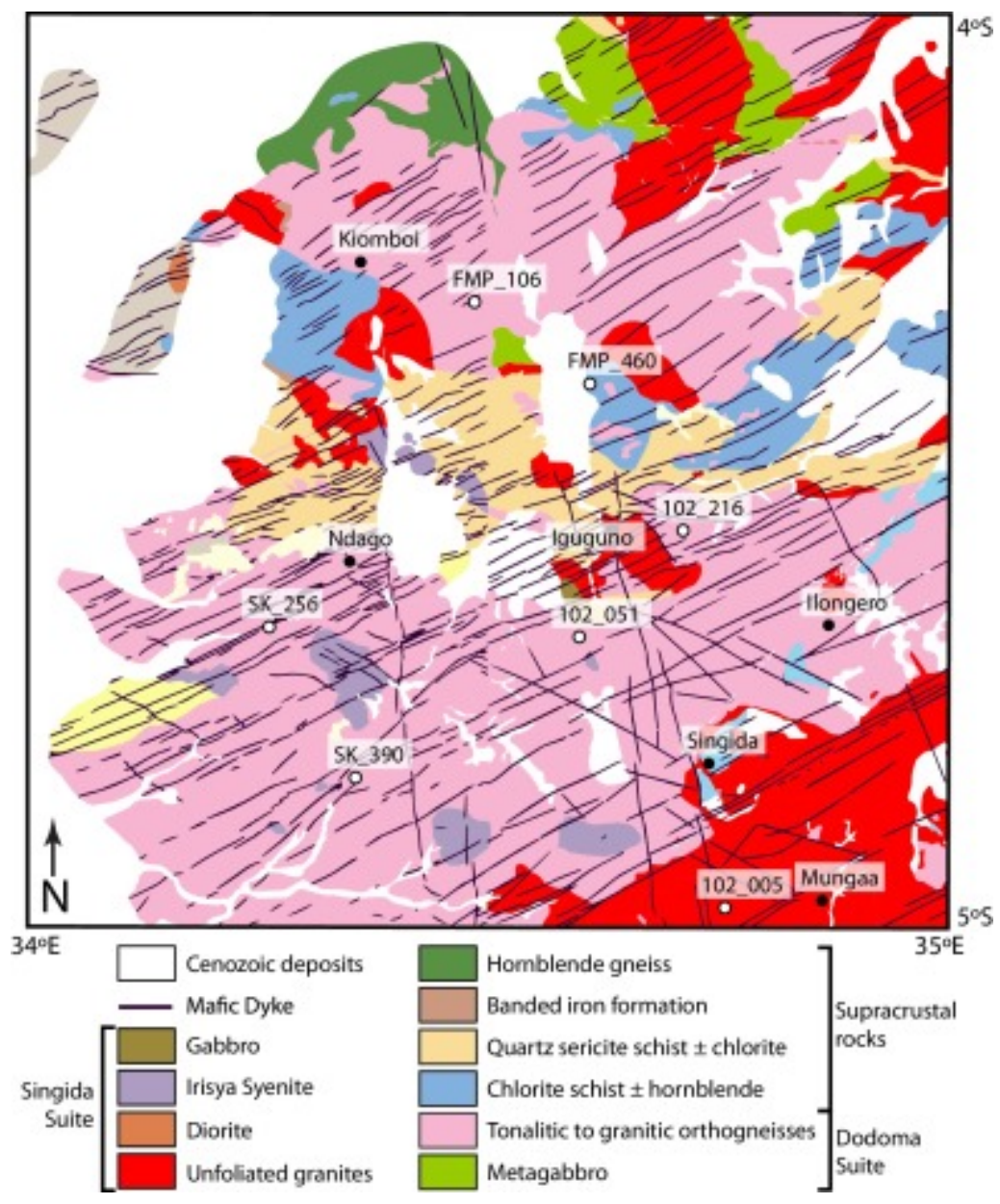


Figure 3: U-Pb concordia diagrams of samples of the Dodoma Suite

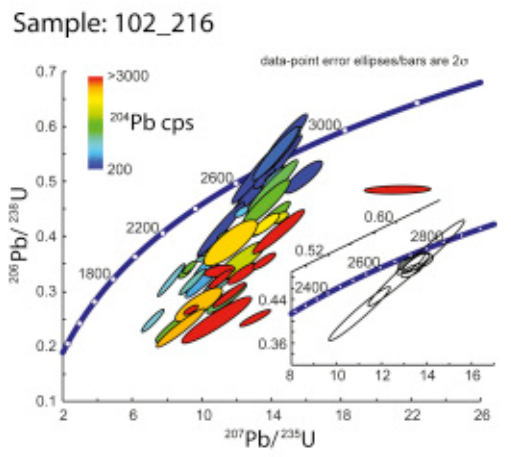

Sample: FMP_A273W

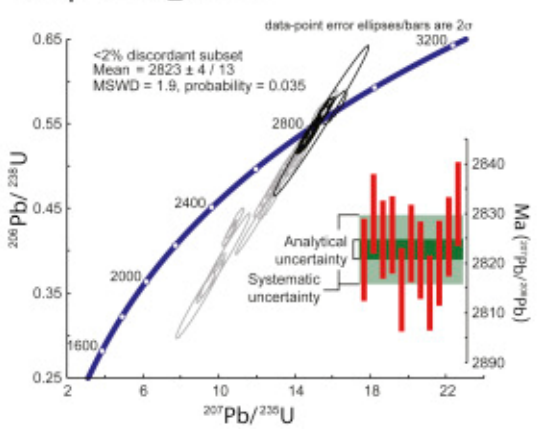

Sample: AMB_178_80

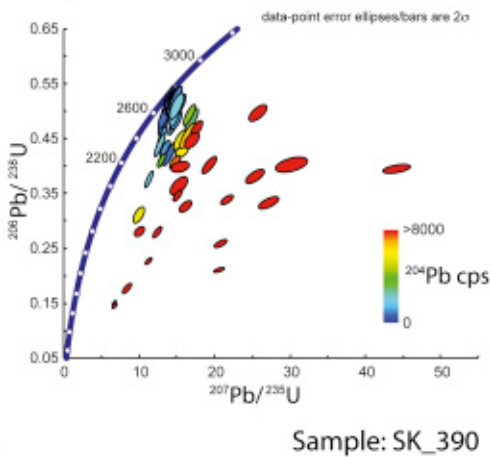

Sample: FMP_106

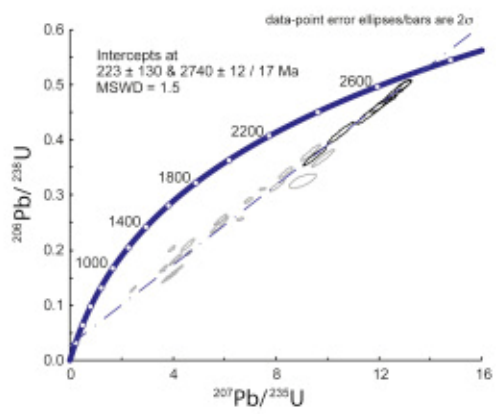

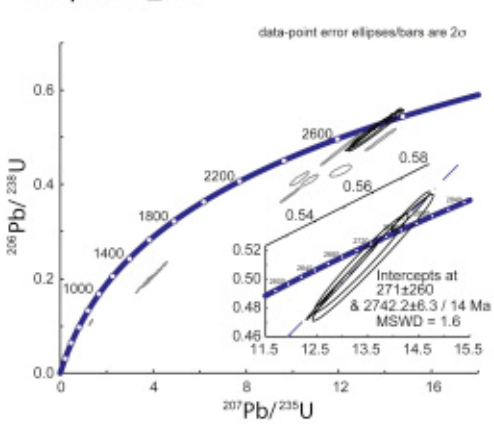

Figure 4: $\mathrm{U}-\mathrm{Pb}$ concordia diagrams of samples of the Craton supracrustal rocks
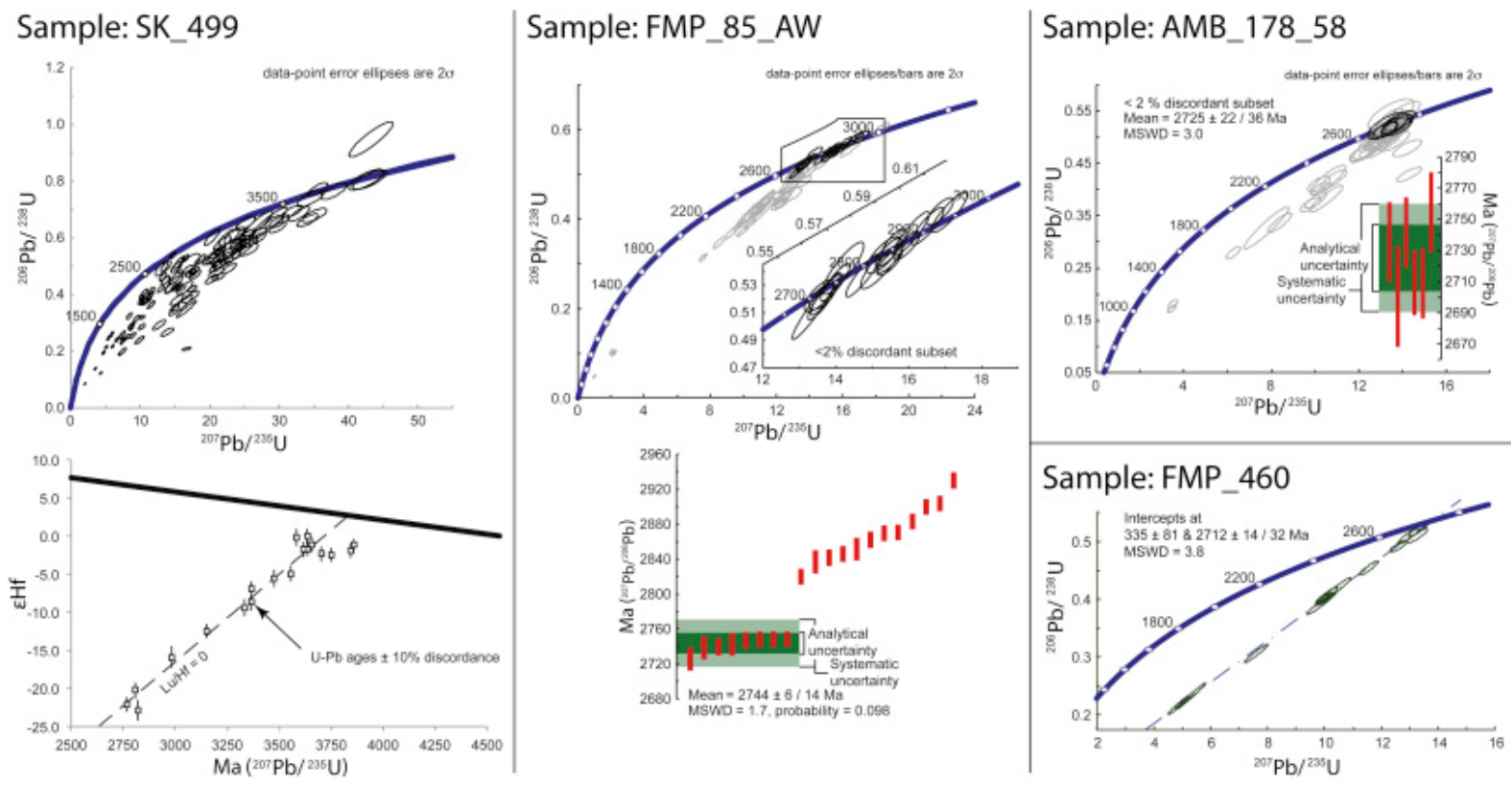
Figure 5: U-Pb concordia diagrams of samples of the Singida Suite

Sample: SK_553

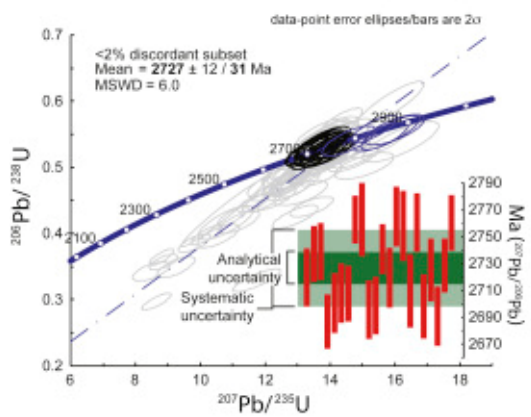

Sample: FMP_A248

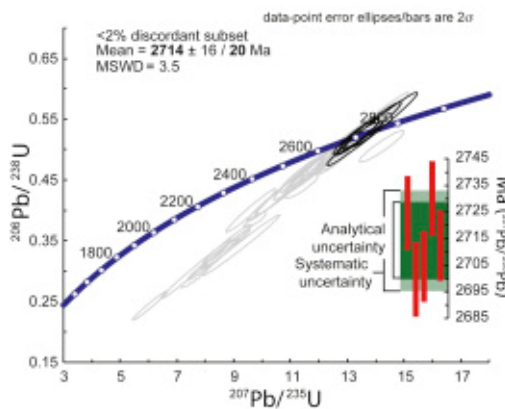

Sample:FMP_78_AW

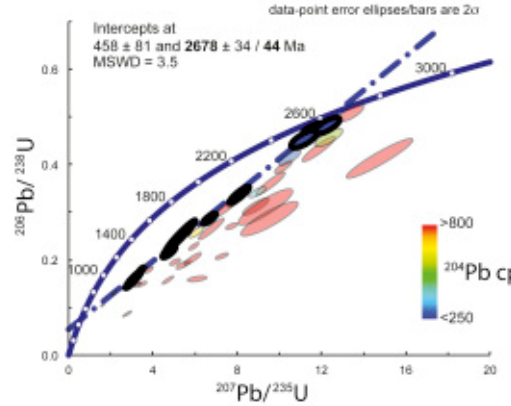

Sample: 102_005

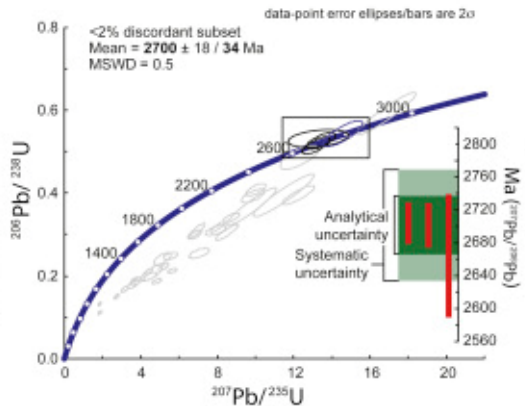

Sample: 102_051

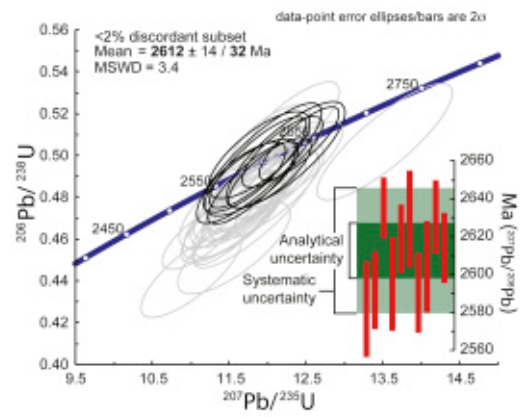

Sample: SK_256

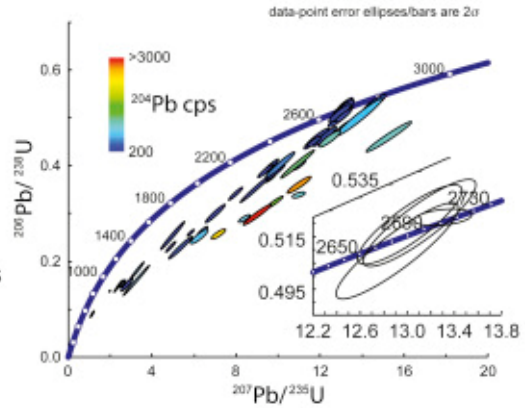

Sample: SK_106

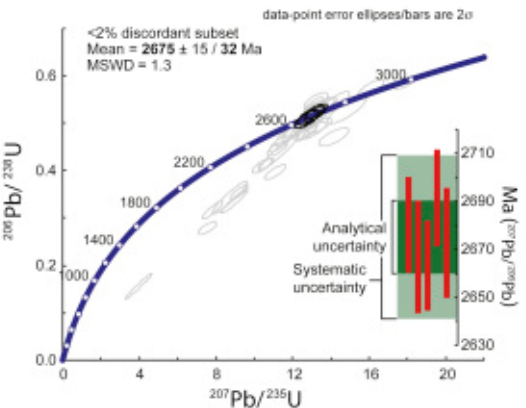


Figure 6: Handeni. U-Pb concordia diagrams of samples of the Handeni Block basement

Sample: ASM_108

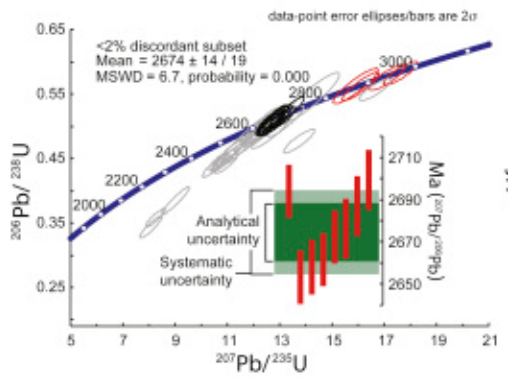

Sample: AMB_203

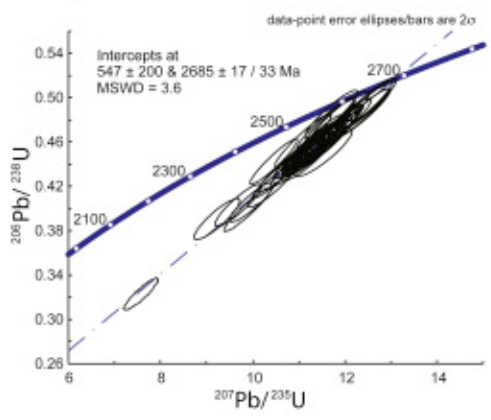

Sample: ASM_120

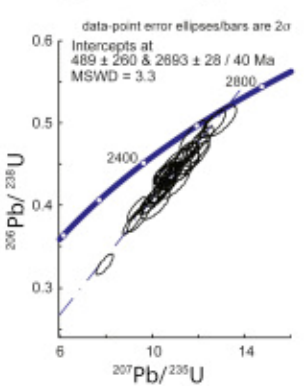

Sample: AMB_213

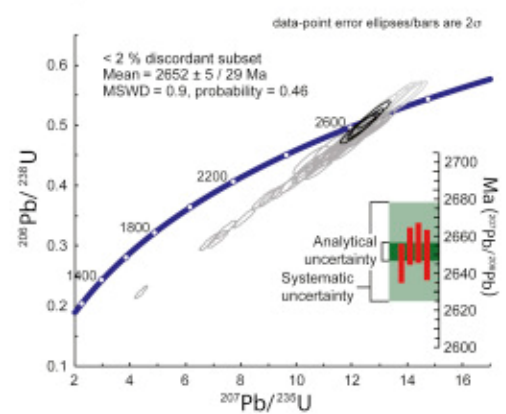

Sample: AMB_14

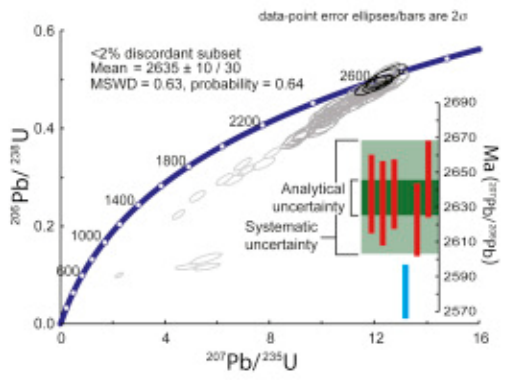

Sample: F_024

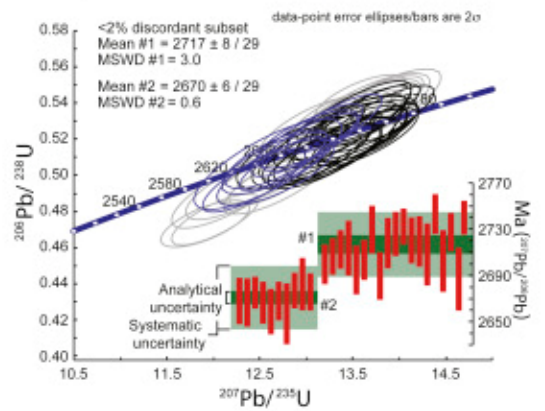


Figure 7: Wami. U-Pb concordia diagrams of samples of the Wami Complex Sample: D_135
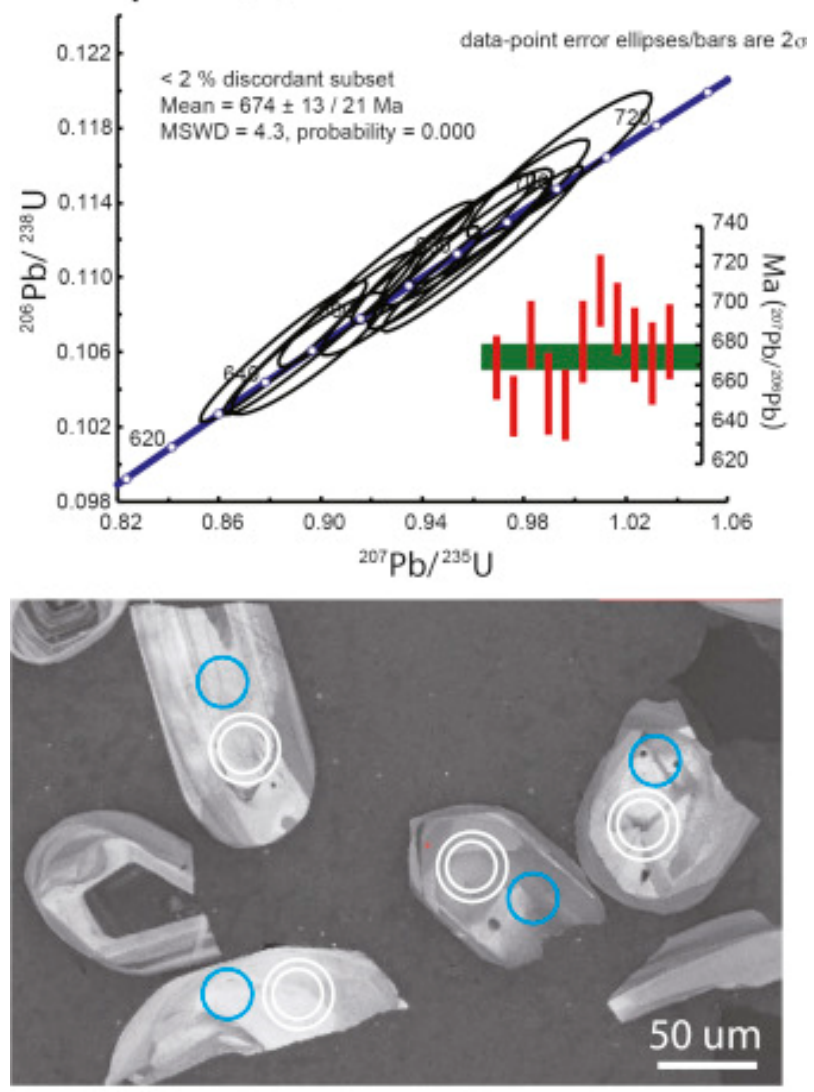

\section{Sample: C_182}
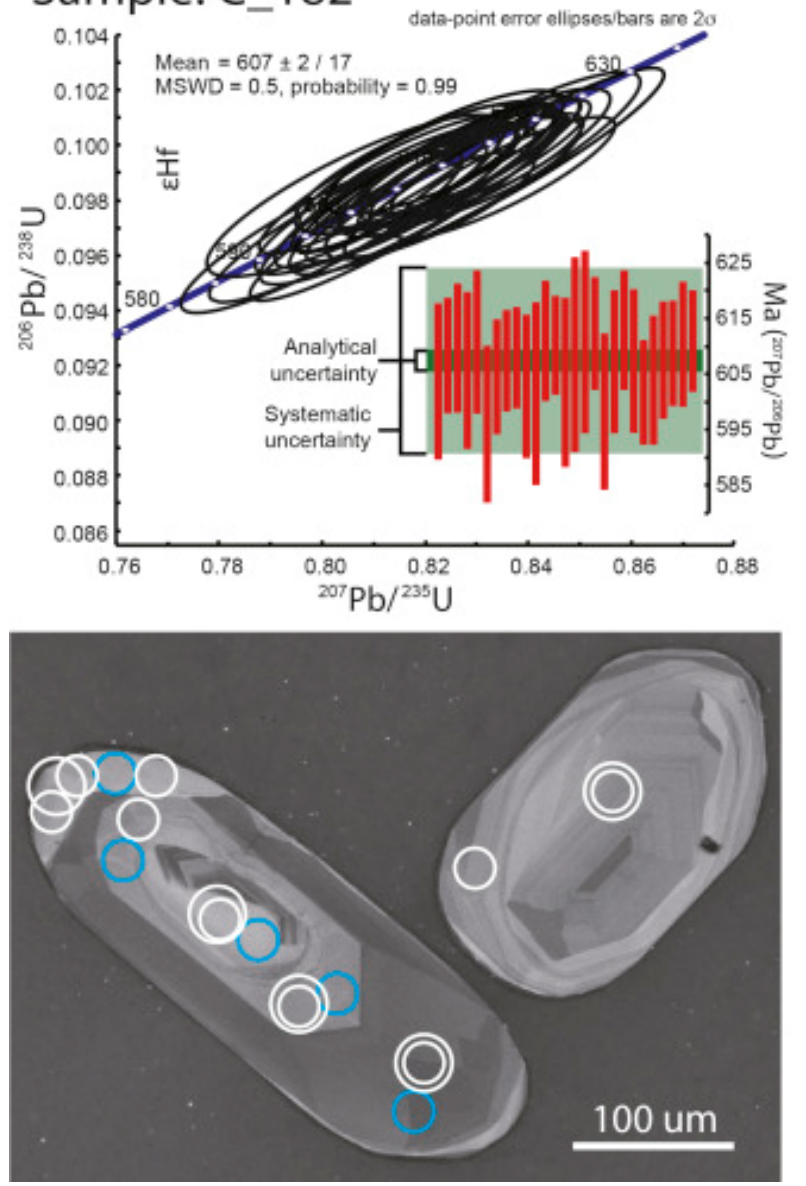
Figure 8: U-Pb concordia diagrams of samples of the Lupa Block

\section{Sample: ASM_238}

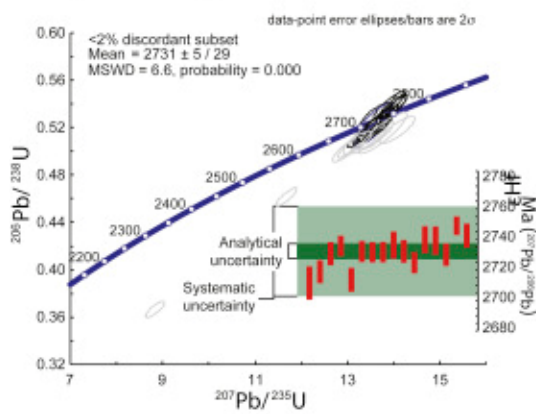

Sample: ASM_271

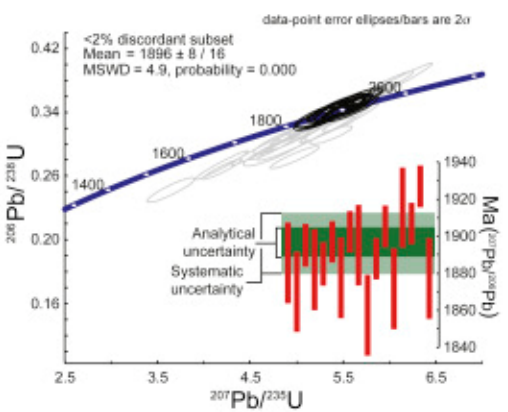

Sample: ASM_470

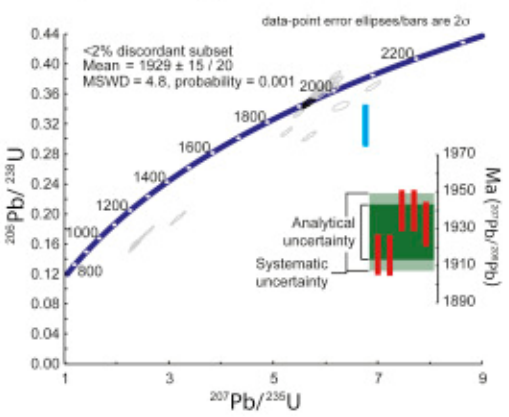

Sample: ASM_364
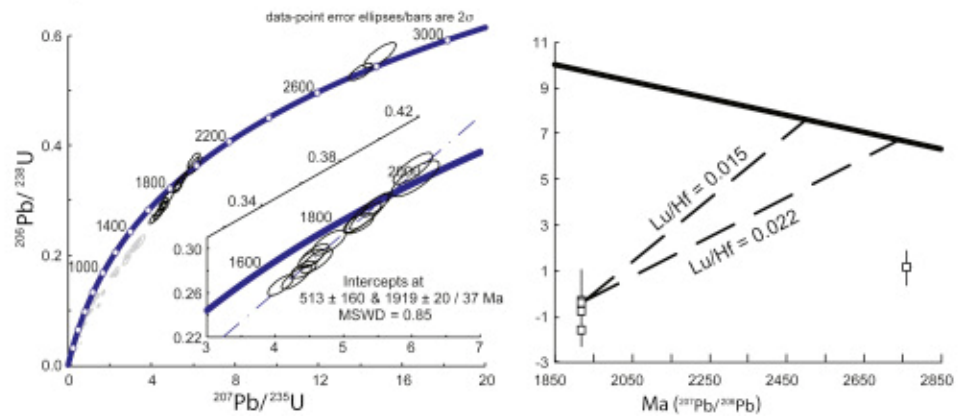

Figure 9: $\mathrm{U}-\mathrm{Pb}$ concordia diagrams of samples of the Lake Malawi block

Sample: ASM_573

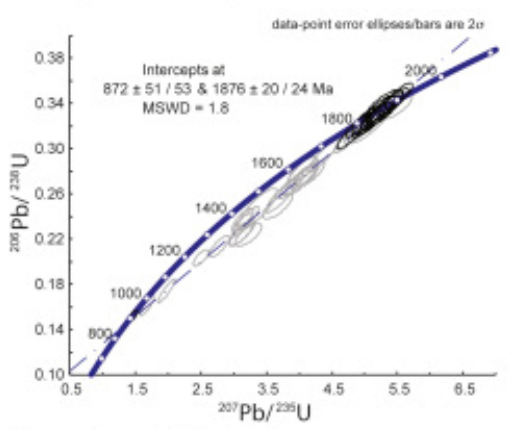

Sample: ASM_496C
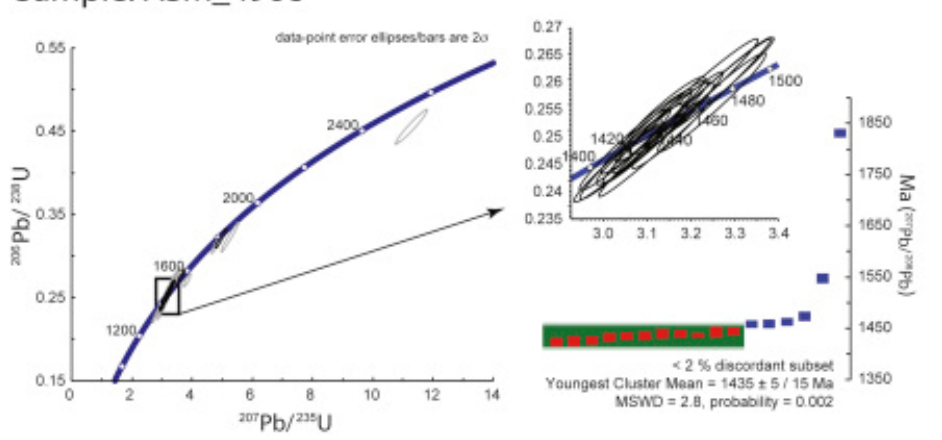

Sample: ASM_590
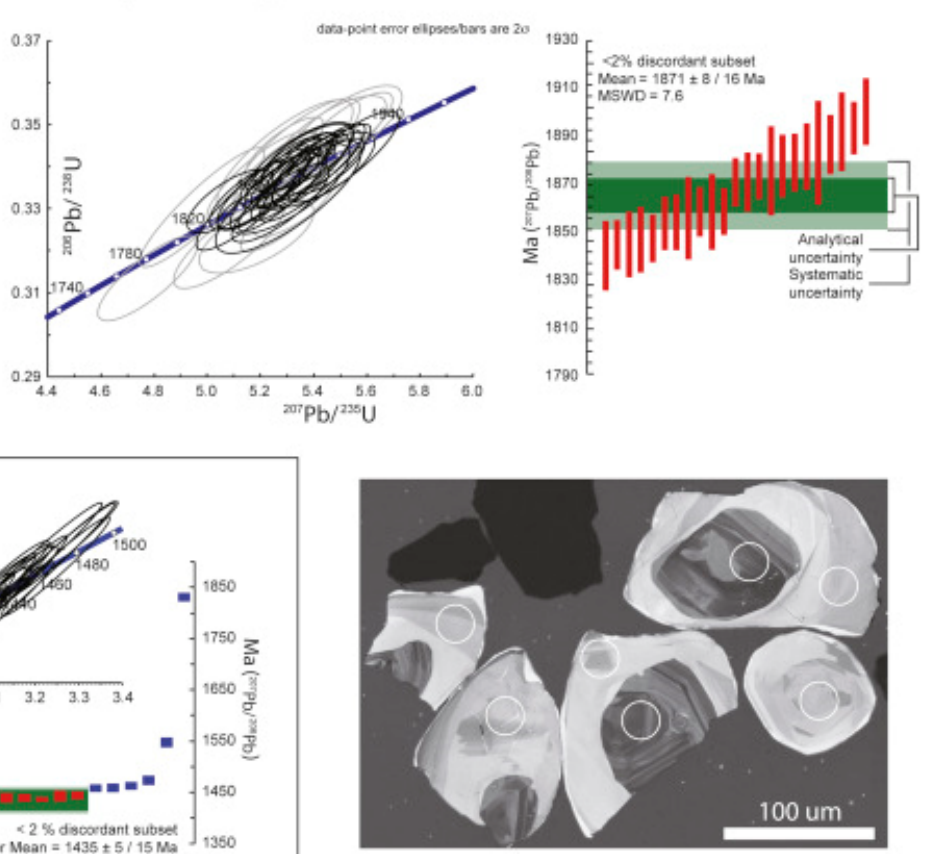
Figure 10: U-Pb concordia diagrams of samples of the Mgazini block
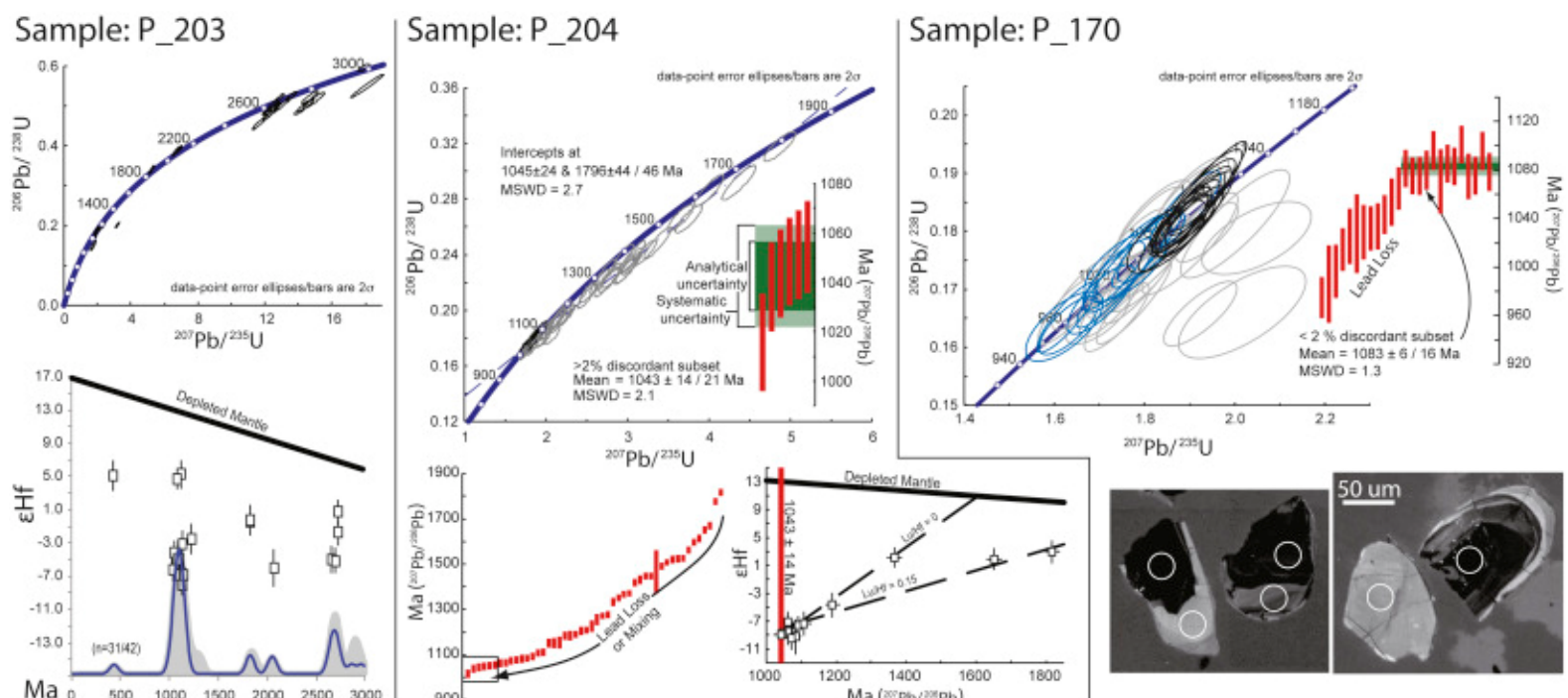

Sample: P_032
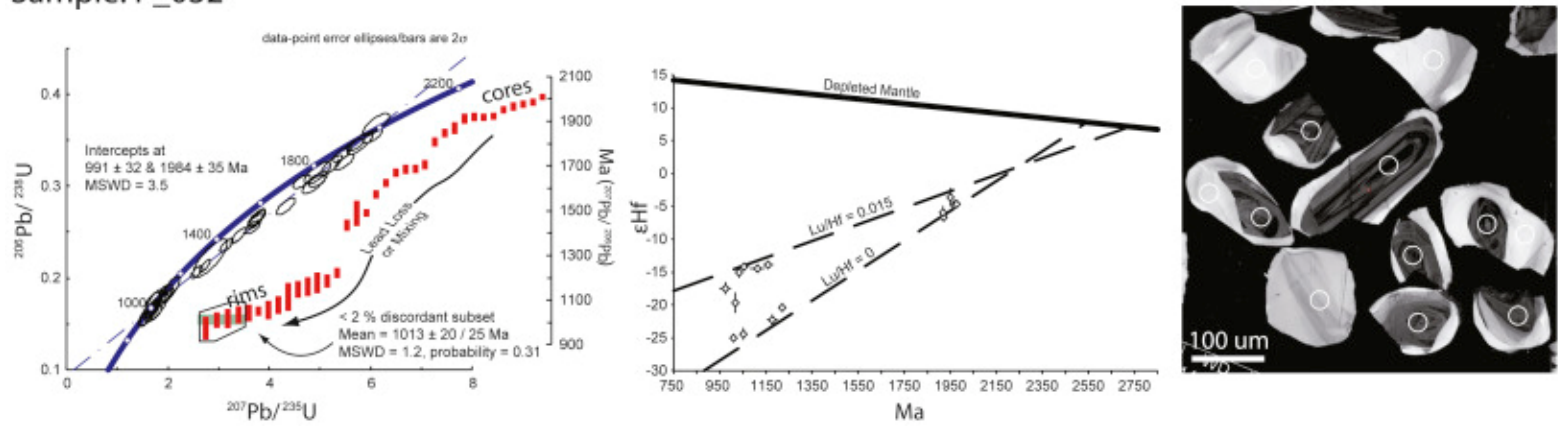
Figure 11:

Summary of ages obtained in this study (legend as for Fig. 1 and Fig. 2).

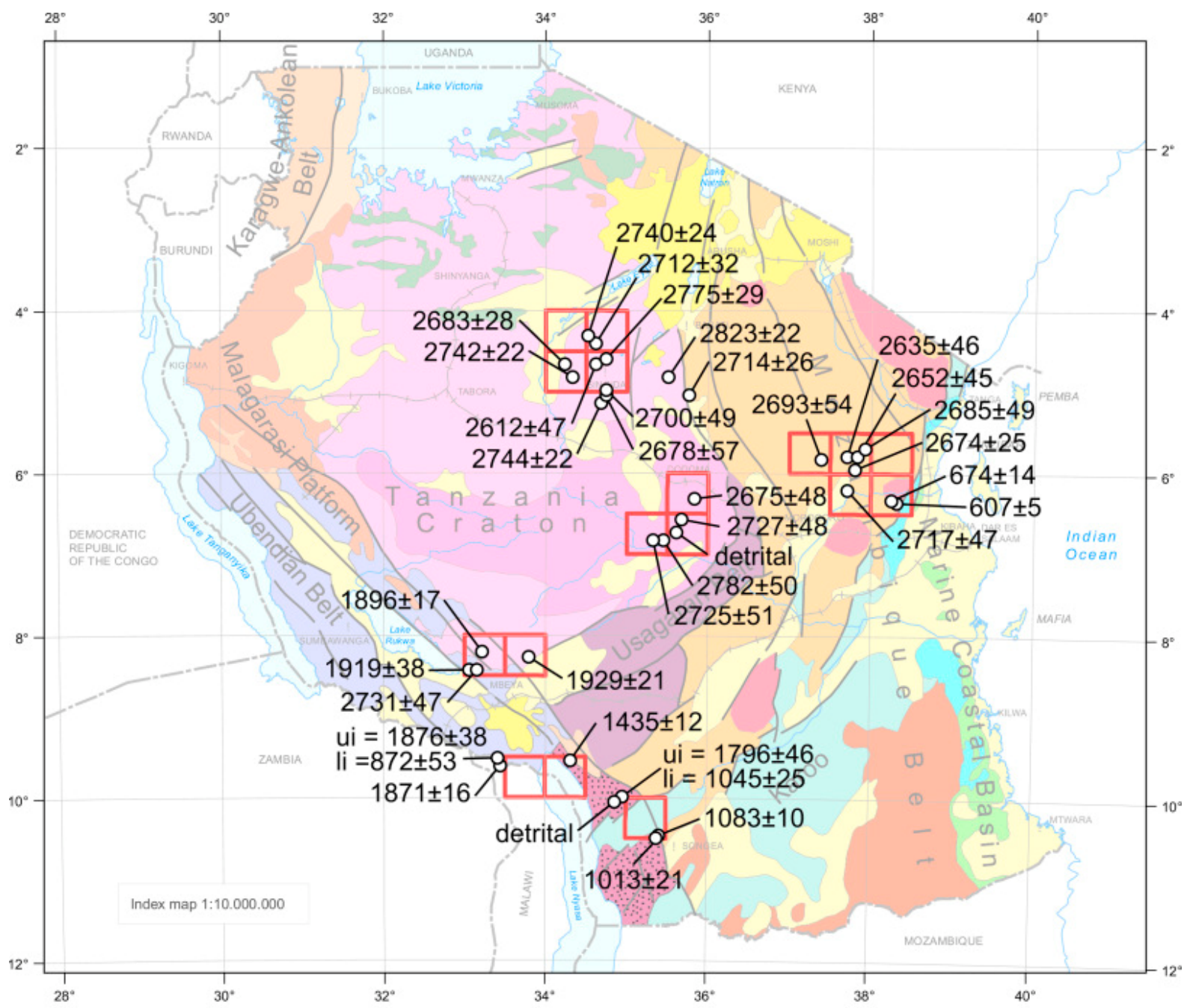

Cenozoic basin and coastal sediments

Cenozoic volcanic rocks

Cretaceous marine sediments

Jurassic marine sediments

rriassic-Upper Carboniferous (Karoo) sedimentary rocks including Permian coals

Neoproterozoic Malagarasi Supergroup

Neoproterozoic granulite complexes (Mozambique Belt) Mesoproterozoic Belt with Neoproterozoic "Pan-African" overprint (Mozambique Belt)

Mesoproterozoic Kibaran Karagwe-Ankolean Belt

Mesoproterozoic Bukoba Group

Palaeoproterozoic Ubendian Belt with Mesoproterozoic overprint

t Neoproterozoic "Pan-African" overprint

Palaeoproterozoic Usagaran Belt

Palaeoproterozoic Ubendian Belt

Mainly Neoarchaean rocks with Neoproterozoic overprint

(Mozambique Belt)

Neoarchaean, Kavirondian and Nyanzian supergroups

Neoarchaean greenstone belts

Meso-Neoarchaean Dodoma Complex 
Figure 12: Time-space diagram of $\mathrm{U}-\mathrm{Pb}$ zircon ages from the various blocks in this study.

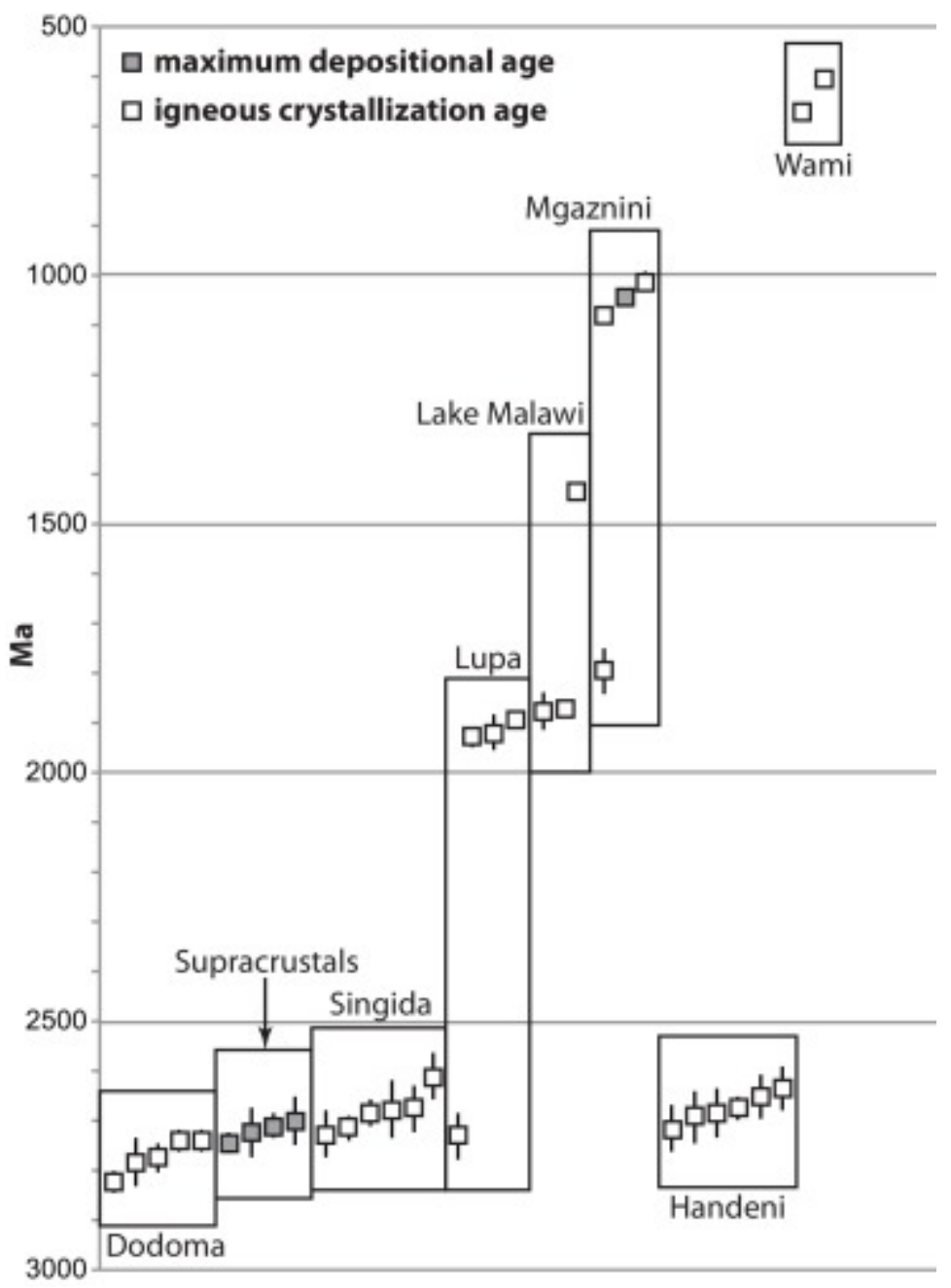


Figure 13:

Summary of the $\varepsilon \mathrm{Hf}$ from this study. Although the $\varepsilon \mathrm{Hf}$ from igneous rocks lie along a well-constrained trend which corresponds to a $\mathrm{Lu} / \mathrm{Hf}$ ratio of 0.028 , it is possible to arrive at the same trajectory through varying proportions of radiogenically depleted and enriched material. Lu/Hf trajectories corresponding to average felsic $(0.015)$ and mafic $(0.022)$ rocks are also shown for reference.

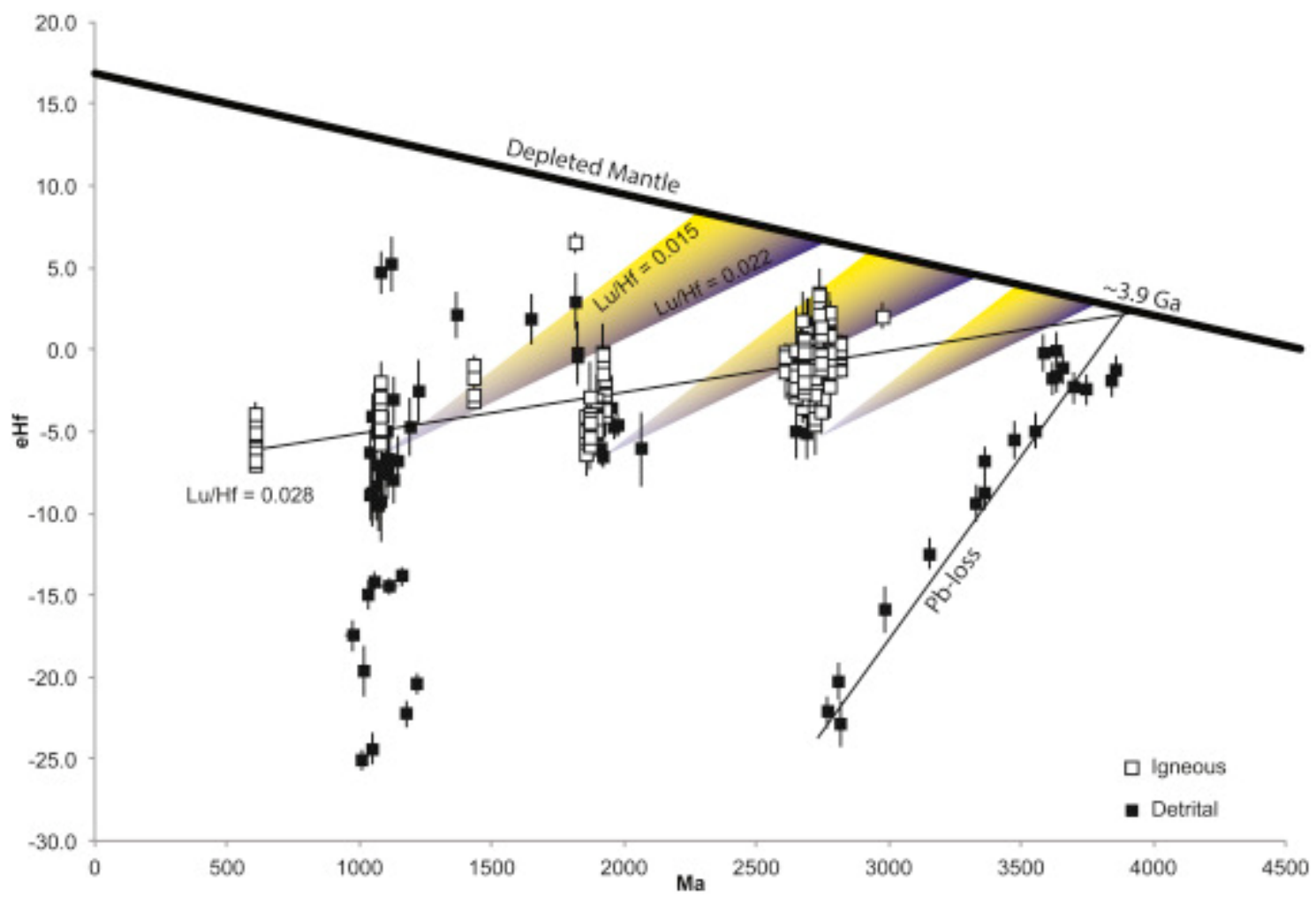

